\title{
CANADIAN
}

\section{SPRING WHEAT} VARIETIES

\author{
J. G. C. FRASER \\ and
}

A. G. O. WHITESIDE

630.4

C212

P 538

1956

c. 3 


\section{TABLE OF CONTENTS}

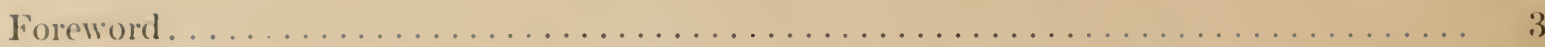

Tey to Varieties of the More Common Hard Red and White Spring Wheats.......... 4

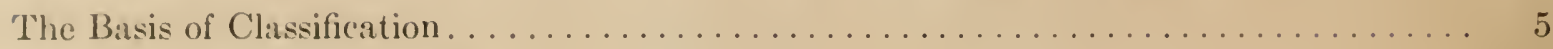

Milling and Baking Qualities................................ 10

VARIETIES:-

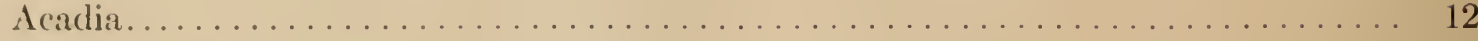

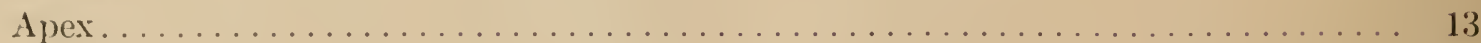

Aurore............................................. 14

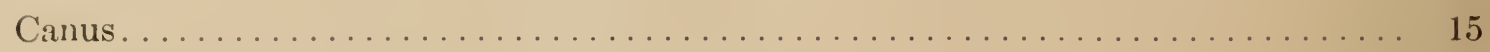

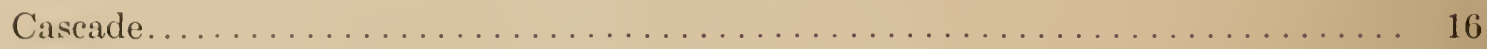

Ceres................................................ 17

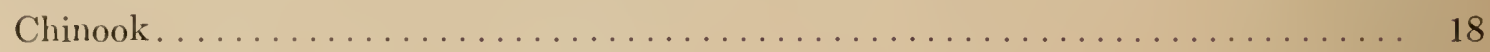

Coronation........................................... 19

Early Red Fife.................................... 20

Federation......................................... 21

Garnet............................................... 22

Hard Red Calcutta....................................... 23

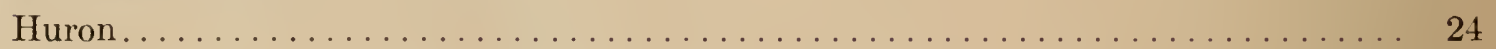

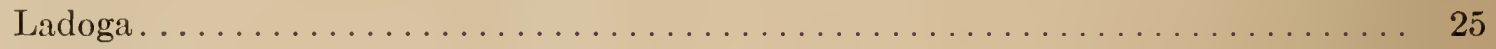

Lake. . . . . . . . . . . . . . . . . . . . . . . . . . . . . . . . . 26

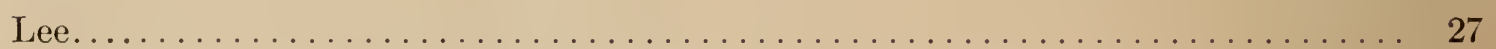

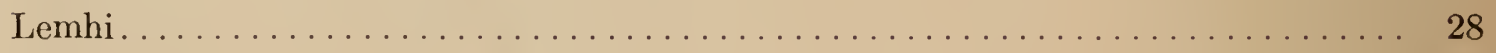

Marquis............................................. 29

Prelude............................................ 30

Preston. . . . . . . . . . . . . . . . . . . . . . . . . . . . . . 31

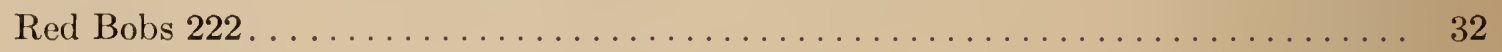

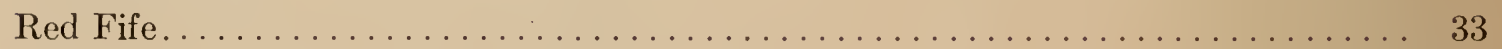

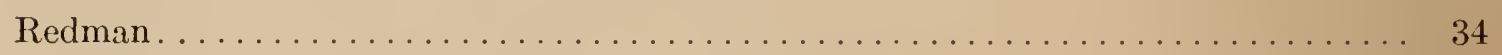

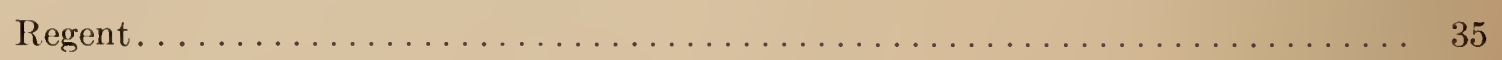

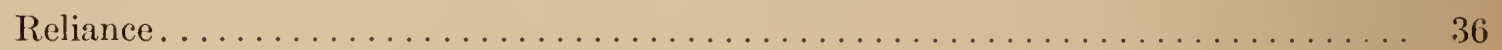

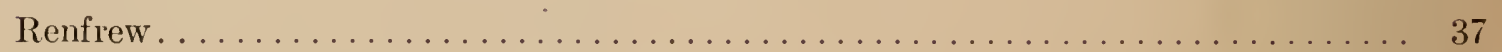

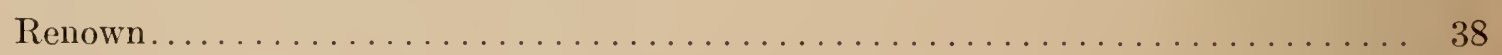

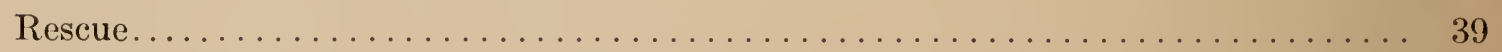

Reward............................................. 40

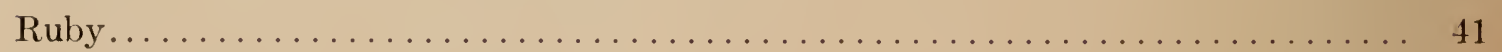

Saunders.............................................. 42

Selkirk.......................................... 43

Stanley............................................. 44

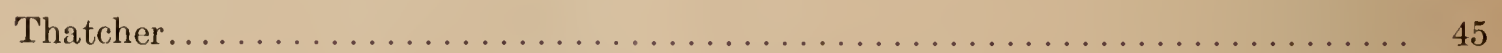

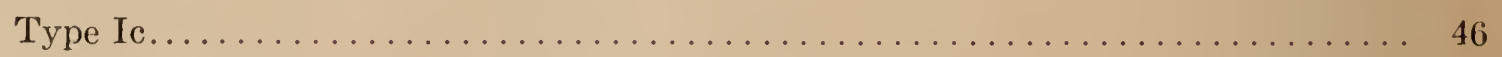

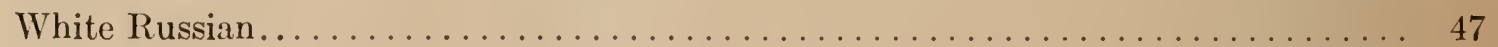




\section{FOREWORD}

The need for definite and precise information concerning the economic qualities and the distinguishing characteristics of the different varieties of spring wheat which are found in cultivation in Canada, is becoming more and more pressing as the number of varieties increases. This need is felt not only by those farmers who wish to grow a variety which is well adapted to their respective conditions but by those officially charged with the inspection of crops for which registration or certification is sought. The plant breeder, the agronomist and the extension man should also be thoroughly familiar with existing varieties and their peculiarities.

Recognising the need for such information, the Cereal Crops Division initiated a systematic study of all varieties of economic interest in the summer of 1924. A brief report covering the work of that year is published elsewhere.* Here reference is made to the attempt to construct a classification or "Key" which might enable one to "run down" or identify a variety of wheat as the botanist uses his key in the identification of a species. It is pointed out that this undertaking was based largely upon the splendid work of Clark, Martin and Ball, of the U.S. Department of Agriculture, Washington, D.C., in their efforts to classify and describe the wheats found in the United States.** Two years later, a second report was presented as a paper before the annual meeting of the Canadian Seed Growers' Association, and duly published.*** In this report, further reference is made to the Key under construction, and to the fact that detailed monographs of each variety would appear later. Since that time, Marquis has been described in detail. $\dagger$ This variety being the most widely grown in Canada at one time and having been taken as the standard of quality in the fixing of the commercial grades, is used very largely in the present publication as a basis of comparison.

*See Proceedings of the Fifth Annual Meeting of the Western Canada Society of Agronomy, Winnipcg, Deeember, 1924.

${ }^{* *}$ Classification of American Wheat Varieties, Clark, Martin and Ball, U.S. Dept. of Agriculturc, Bulletin 1074, Washington, D.C. 1926.

${ }^{* * *}$ Classification of Canadian Spring Wheat Varieties, by L. H. Newman-Report Canadian Seed Growcrs' Association,

† Marquis Wheat-by L. H. Newman and J. G. C. Frascr, Cereal Crops Division, Dominion Experimental Farms: Pamphlct No. 95, New Series. 


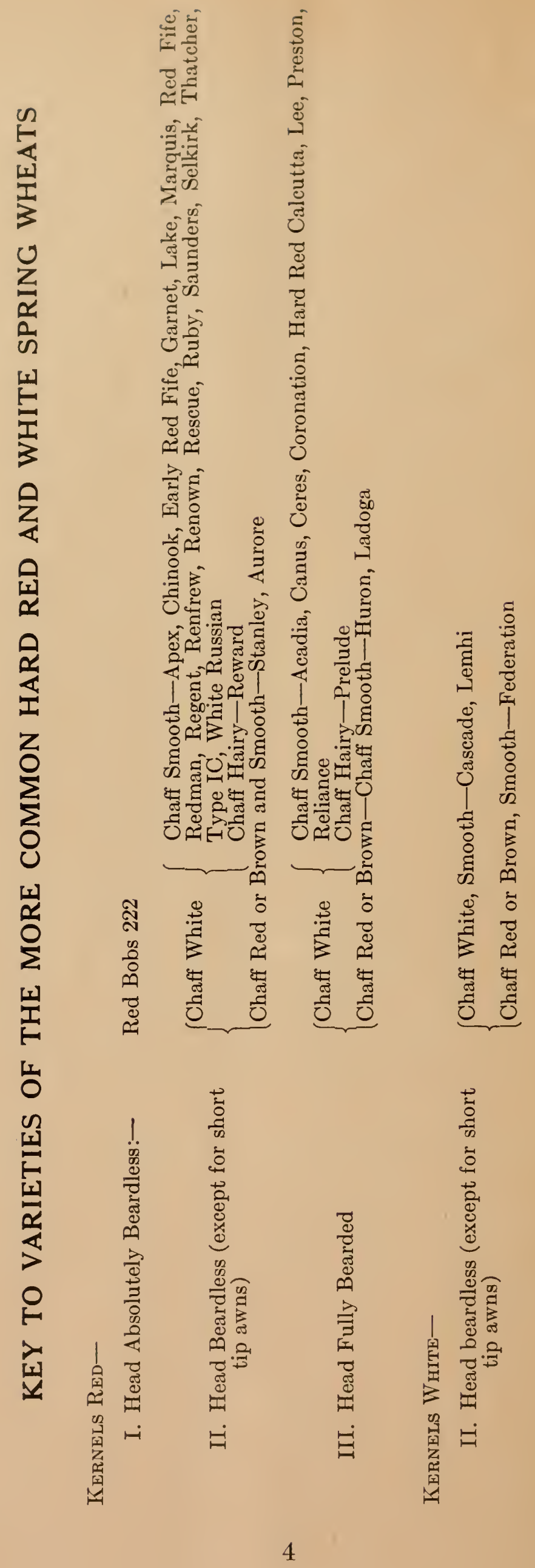




\section{HANDBOOK OF CANADIAN SPRING WHEAT VARIETIES}

\section{THE BASIS OF CLASSIFICATION}

The task of properly appraising a variety of wheat and of describing its peculiarities so that it may readily be recognized, requires that it be grown in many widely separated places and under a great variety of seasonal and other modifying conditions. Such conditions are admirably provided by the Experimental Farms Service with its numerous branch farms and substations scattered from the Atlantic to the Pacific, as well as into the Far North. Here are grown year after year, all varieties on which information is sought so that in the course of time, a fund of information on the peculiarities of each variety is built up.

In constructing a Classification or Key to facilitate the identification of the spring wheats a few major groups may first be segregated. Thus, in the Key herewith submitted, all varieties are divided into two groups on the basis of kernel color-Red Kernelled varieties and White Kernelled varieties. Each of these two groups is then divided on the basis of awn development into three groups or classes, each of which is subdivided in turn on the basis of color of glume or chaff. Finally, all these subdivisions are again split into two sections on the basis of the "hairiness" of the glume.

By means of the above arrangement, it is possible to reduce the number of varieties considered to a relatively small group. It is not difficult to determine the group to which a given variety belongs, but it is often difficult to distinguish the varieties within the group. Here, varieties differ from each other in less apparent characteristics, such as in certain glume characters. These, therefore, have to be dealt with in some detail.

\section{Shape of Head or Spike}

The shape of the spike is of major importance in the classification of spring wheats. In certain varieties, the spike shape is almost sufficient in itself to indicate the name of the variety. In the case of Reward, the spikelets are usually arranged in "zigzag" fashion, thus giving to the variety its characteristic "ragged" appearance. This same characteristic is apparent in many hybrid types of which Reward is one of the parents.

Clark, Martin and Ball define four main types of spike shape, viz., Fusiform or tapering, Oblong, Clavate or "clubbed" and Elliptical. Varieties belonging to the Fusiform group, taper gradually from the base of the spike to the tip. Marquis is a good representative of this group. Varieties classed as Oblong carry their width more uniformly throughout the length of the spike. Renfrew belongs to this group. Spikes which are classed as Clavate or clubbed, vary most. Thus, under very favorable conditions a variety such as Early Red Fife develops thickened club-shaped tips, whereas under conditions which do not favor the full development of the tip spikelets this variety is more oblong in shape. This variety is not to be confused, however, with those belonging to the true club wheats which are extremely dense and compact throughout. 


\section{Density of Spike}

The density or compactness of the spike varies considerably in different valleties. The degree of density is described as lax, mid-dense and dense. Marquis is usually dassed as mid-dense whereas such varieties as Renfrew and White Russian are classed as lax. In the dense group occur such varieties as Aurore.

\section{Awns or Beards}

Varicties which develop no beards whatever are classed as "Absolutely Beardless". Red Bobs is a good representative of this class. Varieties classed as "Beardless" may have short fine awns terminating the lemmas or flowering glumes of the tip spikelets. These "tip awns" differ in length, color, number and arrangement. Marquis, and in fact the majority of the best varieties at present belong to this "Beardless" class.

The varieties which are classed as "Fully Bearded" are those which have a long awn or beard terminating the lemmas. Lee is a well-known representative of this group.

In some varieties, the color of the awn is fairly characteristic and is, therefore, a useful distinguishing character.

\section{Chaff or Glume Characters}

The color, hairiness and shape of the outer glume, commonly called the "chaff", constitute exceedingly important characters from the standpoint of distinguishing one variety from another. Thus, as will be noted in the Key, all varieties are either white chaffed or red chaffed. Then the varieties within each of these two groups are either smooth (glabrous) as in Marquis, or hairy (pubescent) as in Reward.

\section{Length and Width of Glume}

The length-width ratio of the glume is a character of some importance. In some varieties such as Renfrew, the glume is long in relation to its width, whereas in other varieties, the difference is much less.

\section{Shoulder of Glume}

The shoulder is the top or end of the glume, extending from the beak to the opposite margin. It is described by the original authors as narrow, mid-wide and wide (Figure I) while its shape is described as wanting, oblique, rounded, square, elevated and apiculate (Figure II).
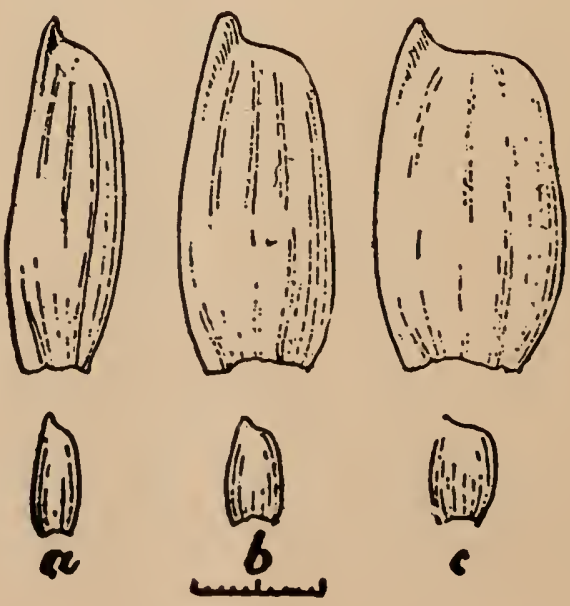

Figure I-Shoulder widths: a, Narrow; b, mid-wide; c, wide. (Natural size and enlarged 3 diameters.) (After Clark, Martin and Ball.) 
The terms used by authorities in the United States have been adopted in the present treatment as they seem to meet all essential needs.
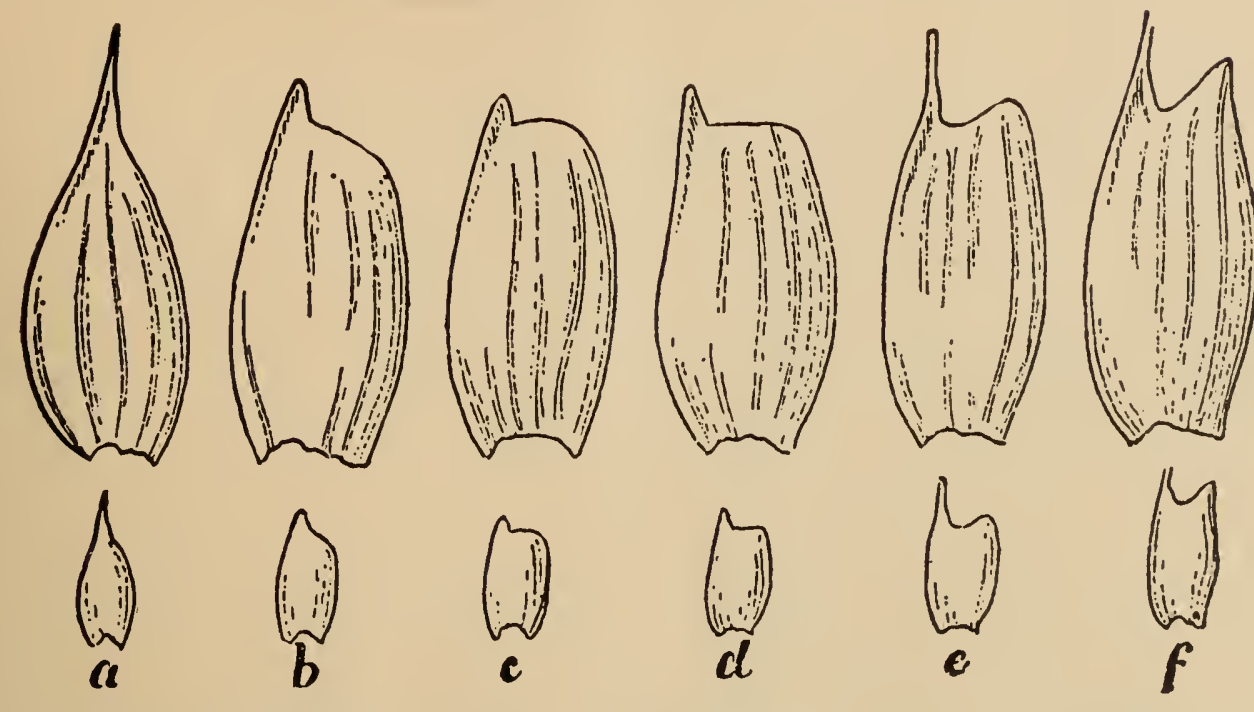

FIGURE II-Shoulder Shapes: a, Wanting; b, oblique; c, rounded; d, square; e, elevated; f, apiculate. (Natural size and enlarged 3 diameters.)

(After Clark, Martin and Ball.)

\section{Beak of Glume}

The projection terminating the keel of the outer glume is called the "beak". These differ appreciably in length and shape. In describing the latter, Clark, Martin and Ball use the terms obtuse, acute and accuminate in describing the shape. It has been found desirable to add an additional term, namely, oblong to describe the beaks of certain varieties such as Early Red Fife (see Figure III).

The length of beak is one of the most valuable distinguishing characters in Spring Wheats, as each variety has its own characteristic beak length (Figure IV).

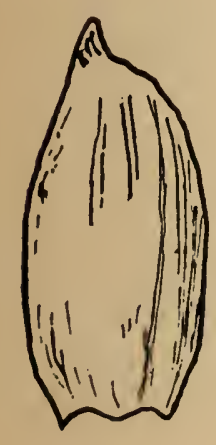

A

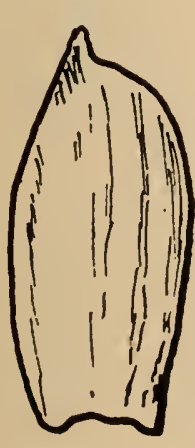

B

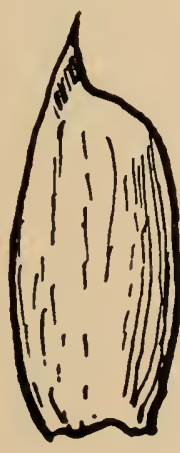

C

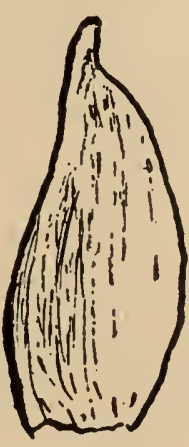

D

Figure III-Beak Shapes: A, obtuse; B, acute; C, accuminate; D, oblong. (Adapted from Clark, Martin and Ball.)

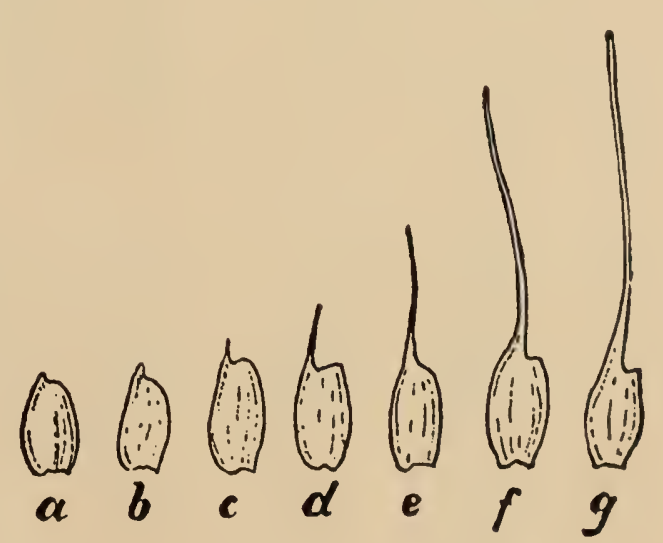

Figure IV-Beak Lengths, showing seven variations (natural size). (After Clark, Martin and Ball.)

In comparing the glumes of one variety with those of another, it is desirable to choose glumes borne by spikelets occupying the same position on each head. In this connection, it has been found that glumes at the 7 th node from the base of the head are usually the most uniform and, therefore, the most reliable. It has also been found that the glume of the two outer spikelets, viz., the primary and the secondary should both be used. 
Figure $V$ shows the glumes of a number of the more distinctive varieties in order to illustrate the different types of glume which characterize different varieties.
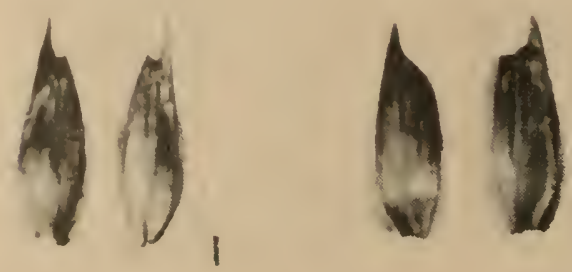

2

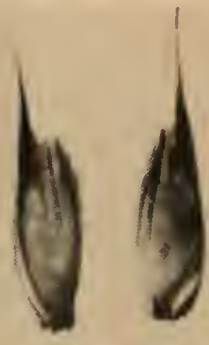

3
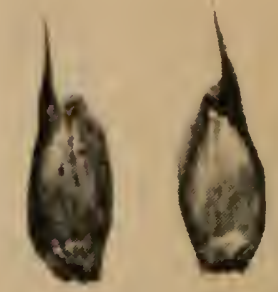

4
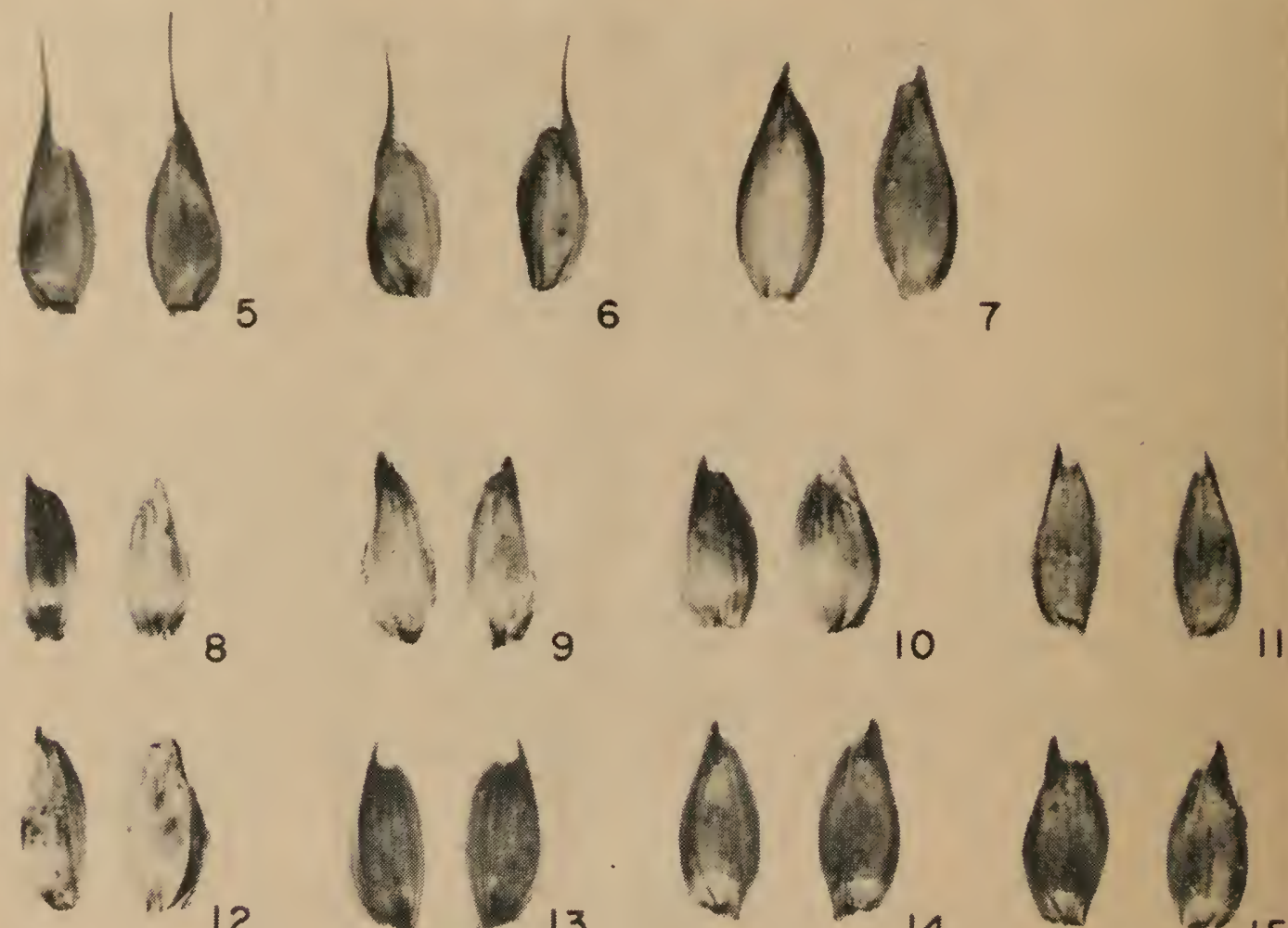

12
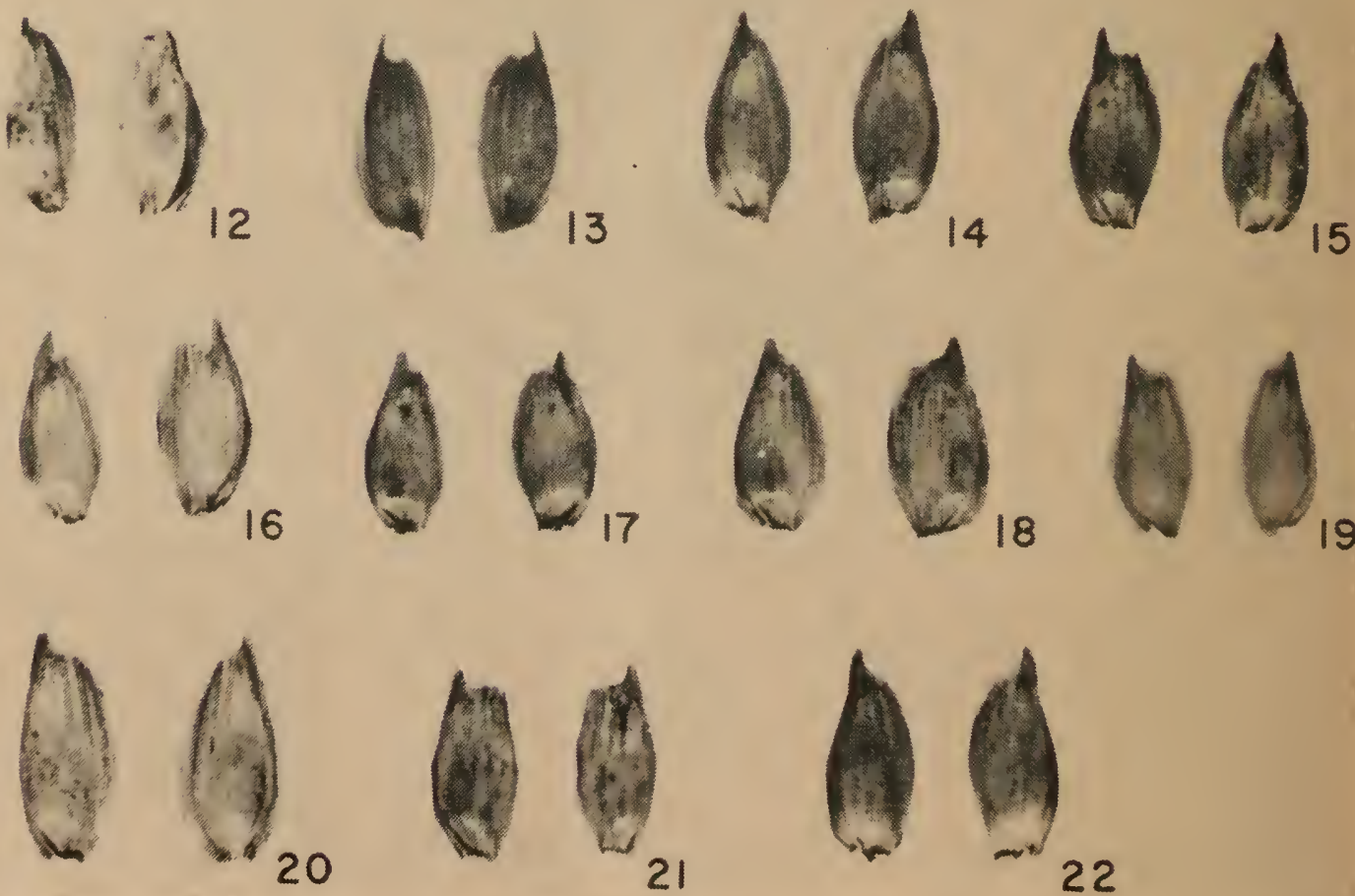

Figure V-Primary and secondary glumes of the more common spring wheats.

(1) Huron, (2) Ceres, (3) Canus, (4) Coronation, (5), Acadia, (6) Lee, (7), Lake, (8) Red Fife, (9) Early Red Fife, (10) Marquis, (11) Garnet, (12) Red Bobs 222, (13) Renown, (14) Regent, (15) Redman, (16) Thatcher, (17) Rescue, (18) Saunders, (19) Cascade, (20) Lemhi, (21) Chinook, (22) Selkirk. 


\section{Kernel Characters}

The kernel characters which are most useful in distinguishing Canadian varieties are (a) color, (b) length of kernel in relation to its width and (c) obliqueness of the germ face.

While kernel characteristics may vary somewhat under different environmental conditions, each variety has its own characteristic color and shape.
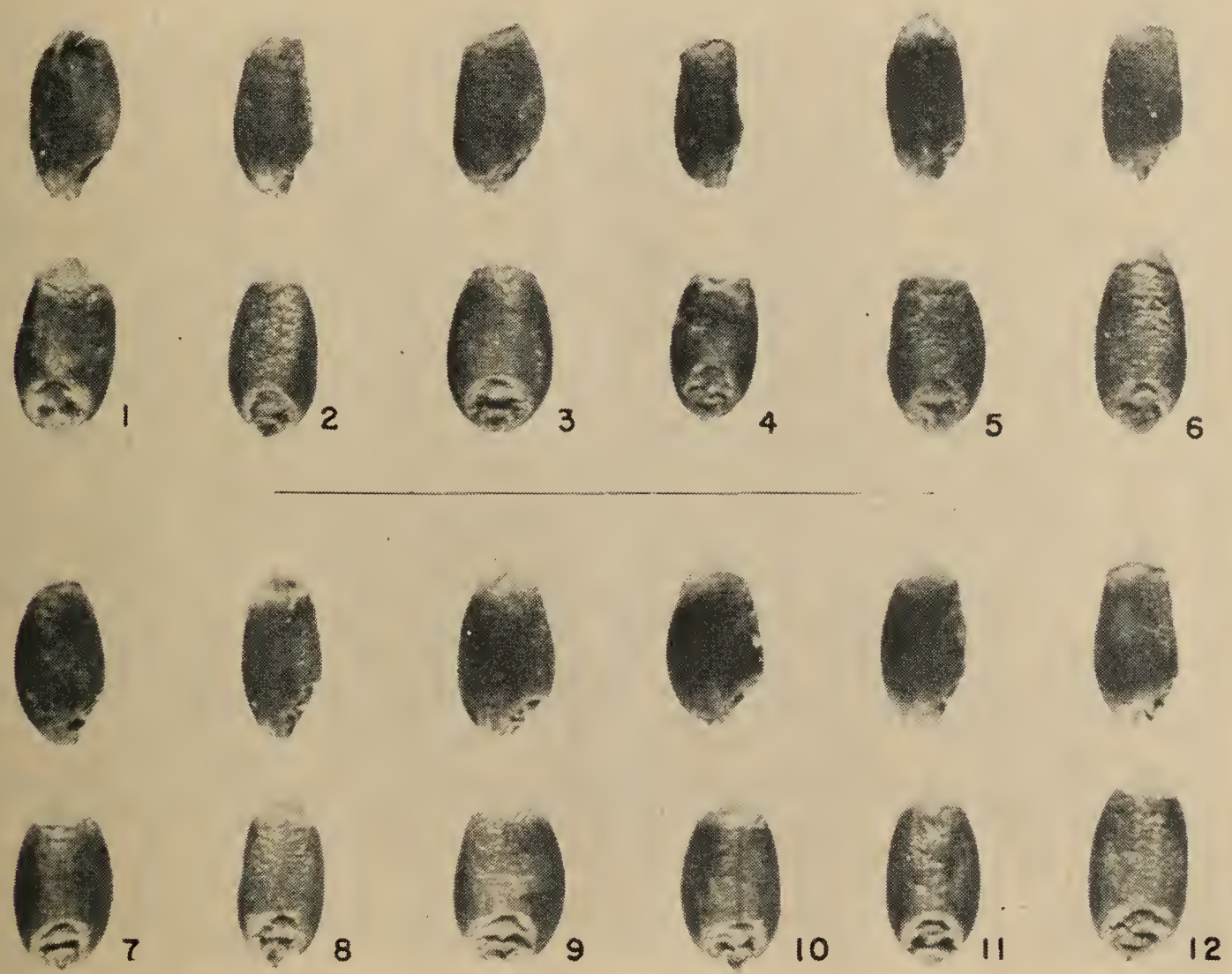

Figure VI-Kernels of (1) Lee, (2) Lake, (3) Marquis, (4) Garnet, (5) Regent, (6) Redman, (7) Thatcher, (8) Rescue, (9) Reward, (10) Saunders, (11) Chinook, (12) Selkirk, showing dorsal and lateral views.

CoLor: As already indicated, all varieties of spring wheat are divided into two main color groups, Red and White. Within the former group may be found varieties which are dark red as in Reward, and others, such as Acadia, which normally may be described as light red. Between these two extremes may be found many varieties which differ only very slightly in color.

In recent years, it has been found that the grains of certain varieties when immersed in a solution of phenol, take on different colors. Thus Marquis when treated, assumes a very dark brown color, whereas Red Bobs remains practically unaffected.* These observations would seem to indicate the possibility of using these treatments as an aid in distinguishing varieties.

Length-Width Ratio: As in the case of the glumes, the length-width ratio of the grain, that is the length in relation to the width, appears to be a more satisfactory basis of comparison than are either the width or the length when considered independently. Thus certain varieties, such as Garnet and Huron, are usually longer in proportion to their width than are varieties such as Reward

" "Two New Methods of Distinguishing Canadian Wheats"-J. G. C. Fraser and F. Gfeller, Scientific Agr. 15/8/35.

$77487-2$ 
and Marguis. This fact makes it possible to distinguish four main shapes of kernel when the latter are normally developed, viz., (a) ovate or egg-shaped, (b) elliplical, (c) oblong and (d) oval.

GERM FACE: While the size and shape of the "face" of the germ or embryo are of little value from the standpoint of classification, the degree of "obliqueness" of the germ has proved of some value in a few cases. Thus, in Garnet, the obliqueness of the germ differs from that of most of the common varieties.

Bnusn: The small hairs at the tip of the kernel, commonly known as the brush, vary considerably in length and number in different varieties and frequently may be used to advantage.

\section{MILLING AND BAKING QUALITIES}

In Western Canada, the climate and soils are suited to the production of high quality bread wheat and this fact together with the growing of high quality wheat varieties contributes to the reputation enjoyed by Canadian wheat in the markets of the world. The desirable qualities of a good bread wheat are largely associated with the quantity and quality of its protein. The quantity of protein is influenced mainly by environmental factors. Soil moisture, available soil nutrients especially nitrogen, and seasonal temperatures have a bearing on the protein content from place to place and from season to season. When soil moistures are low and the seasonal temperatures are above normal the protein content of the wheat will usually be high and when soil moistures are high and seasonal temperatures low, protein content will be low. It has been shown as well that cropping methods affect wheat protein; wheat following summerfallow usually being higher in protein than wheat following another crop. On the other hand, the quality of the protein is largely an inherent varietal characteristic and a high quality variety will produce good bread over a fairly wide range of protein percentages but a low quality variety will still produce relatively poor quality bread even when its wheat protein content is high.

Since the qualities of Marquis are recognized and accepted as the standard and since it is this variety upon which are based the official grades for red spring wheat as designated in the Canada Grain Act, other varieties are assessed in relation to Marquis. Wheat of this type when grown in the better wheat producing districts in Western Canada, possesses a quality of protein which imparts to the dough, tough and elastic properties which make it high in baking strength. Importing countries such as England, use this wheat to blend with wheat of lower baking strength and look upon it as the strong component of the mill mix. Some varieties, such as Thatcher, produce wheat of higher baking strength than Marquis when grown under the same environmental conditions. Other varieties exhibit lower baking strength. Some varieties mill better than Marquis while others are poorer in this respect. Certain varieties produce yellow flour in contrast with the creamy white flour milled from Marquis.

Wheat improvement programs in Canada have been based not only on providing good agronomic varieties for the different wheat-growing areas but on maintaining or improving upon the Marquis quality type. Marquis has fallen from its one-time high when it occupied about 90 per cent of the wheat acreage to less than 4 per cent at the present time. Some varieties are more suited agronomically for certain areas such as those in Manitoba and in eastern Saskatchewan where resistance to stem rust is required. Suitable agronomic varieties have been developed for other regions. Some varieties such as Thatcher are more widely grown than others and therefore, exhibit a greater influence on the general quality of our wheat. Varieties now found in Western Canada considered equal to Marquis for purposes of commercial grading into all Manitoba Northern grades are Thatcher, Selkirk, Lee, Saunders, Chinook, Redman, Marquis, Regent, 
Apex, Lake, Reward, Renown, Canus, and Reliance. Rescue is considered not quite equal to Marquis while Red Bobs is classed as a fair milling wheat and will grade no higher than No. 3 Manitoba Northern. Garnet is grown to a limited extent in the northern regions. It has been graded into special Garnet grades since 1935 as it is different in milling qualities and inferior in baking strength to those varieties classed as equal to Marquis.

A soft white spring wheat, Lemhi is grown on irrigated land in southern Alberta. This is a special type of spring wheat which is used for milling into pastry and cake flour but is poor for making bread. In other areas only high quality red spring wheat varieties are recommended, as the red wheats, as a class, are distinctly superior, all things considered.

\section{VARIETIES RECOMMENDED}

The varieties of spring wheat that have proved most suitable for the main wheat-growing regions throughout Canada are designated elsewhere. In most provinces Cereal Variety Committees make annual recommendations for each area within the province and one should be guided by these recommendations. As new varieties of proved merit come to compel attention, changes will take place in these recommendations. To keep up-to-date, growers should keep in touch with the tests being conducted at the nearest Experimental Farm or by provincial Departments of Agriculture. 


\section{Acadia}

\section{(C.A.N. 3541)*}

Origin: Acadia is a selection made in 1937 at the Experimental Farm, Indian Head, Sask., from a cross 2575 made at Ottawa in 1934, between Canus $\times$ R.I. T29) (Marquis $\times$ Pentad).

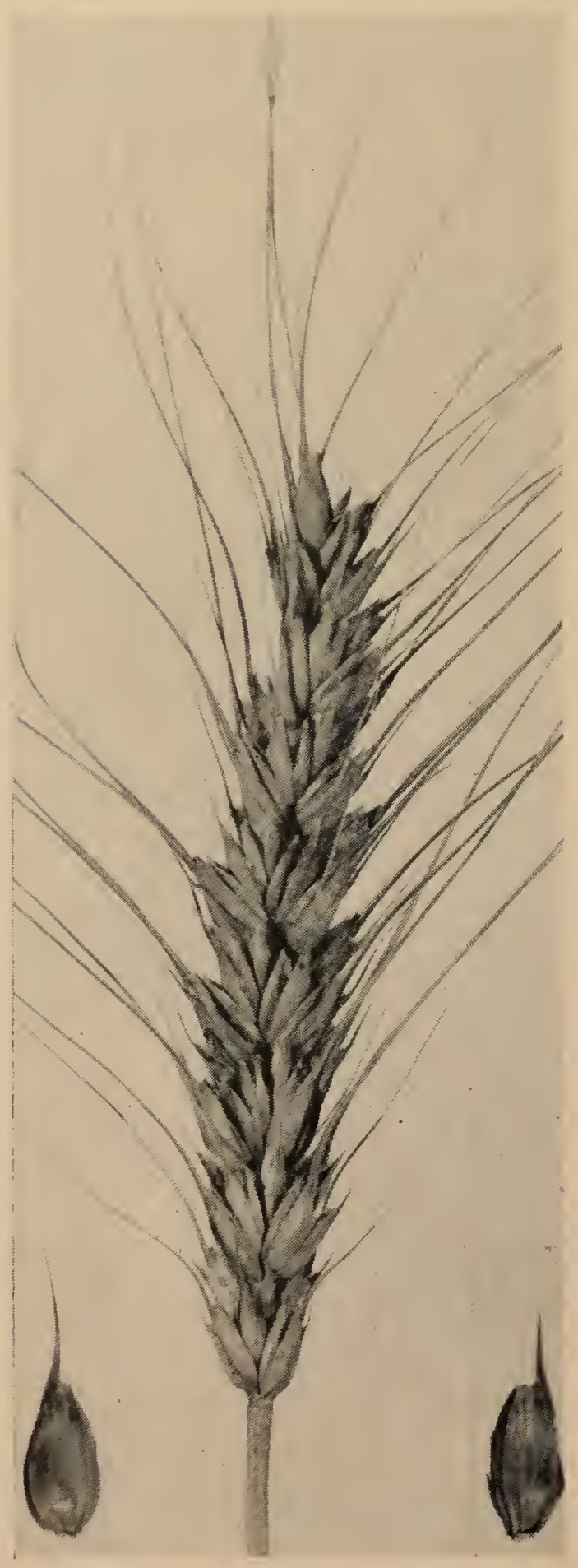

ACADIA

C.A.N. 3541

Acadia was grown in tests in Eastern Canada from 1942 to 1951 , under designation C.D. 3285. It was recommended for license in 1951 "as a wheat for use in Eastern Canada", where it has been a consistently high yielder. It was accepted for registered status in 1952 .

Description: Head bearded, fusiform; chaff white and smooth; shoulders mid-wide and oblique; beaks long and slightly barbed; kernels light red, elliptical to ovate; matures a few days ahead of Marquis; resistant to bunt and black chaff; moderately resistant to stem and leaf rust; semi-resistant to loose smut and root rot.

Milling and Baking Qualities: Not equal to Marquis in quality, being slightly lower in protein and loaf volume. Not recommended for use in Western Canada.

Status and Distribution: Seed was distributed to over 200 farmers in Eastern Canada in 1953. At the present time Acadia is the most generally grown spring wheat in Eastern Canada. 
Apex

(C.A.N. 1857)

(Original Station Nos.: A. 75-1; Sask. 1703)

Origin: From a cross made at the University of Saskatchewan, Saskatoon, Sask., in 1927, between (H-44-24 × Double Cross) and Marquis.

Description: General shape and size of head very similar to Marquis but tip awns generally shorter; beaks slightly sharper; elevation of the shoulder greater than in Marquis with less narrowing of the shoulders towards the tip of the spike. Apex yields fully as well as Marquis under normal conditions but much better when rust is bad. Under practically all conditions it yields less than Thatcher. It has proved moderately resistant to stem rust, and to bunt and loose smut, but susceptible to leaf rust.

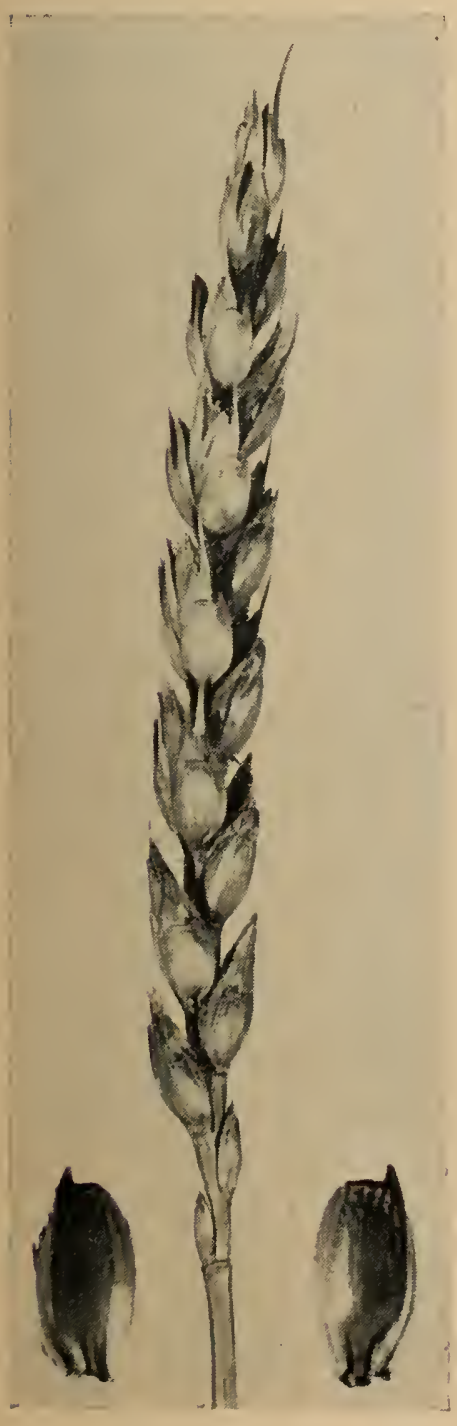

Apex

In maturity there is no essential difference between Apex and Marquis but both are usually a few days later than Thatcher and Renown. The kernel of Apex resembles that of Marquis in all important respects. In strength of straw, Apex is slightly weaker than either Marquis or Thatcher especially in Manitoba, while in height it is slightly taller than the latter although somewhat shorter than Marquis.

A selection out of Apex (Sask. 1789) has become the basis of registered seed of this variety.

Milling and Baking Qualities: Apex closely resembles Marquis in all essential milling and baking characteristics.

Status And Distribution: Some 1,250 bushels of Apex were distributed in the rust areas of Saskatchewan in the spring of 1937. Unfortunately, the total returns for that year were rather low owing to the severe drought prevailing in most of the districts wher: sown. The season of 1938, however, was more favorable, and approximately 20,000 bushels of this variety were available for seeding in the spring of 1939 . Since the appearance of race $15 \mathrm{~B}$ stem rust, the use of Apex has declined and in 1955 only 1 per cent of the acreage in Saskatchewan and 1 per cent of the acreage in Alberta were sown to this variety.

C.A.N. 1857 


\section{Aurore}

(C.A.N. 1218)

()RIGN: This variety originated in Australia from a cross made by $\mathrm{Wm}$. Farrer betwen Jacinth, a Colorado wheat, and the Russian variety Ladoga. It was brought into Canada for testing in 1920 by the Cereal Crops Division, ()ttatia.

1)Escription: Head of medium length, oblong and fairly dense; beardless except for a few short tip awns; chaff reddish brown and smooth, with square shoulders of medium width and with short acute beaks; kernels of medium length but rather narrow; maturing slightly earlier than Marquis; straw slightly shorter and weaker than

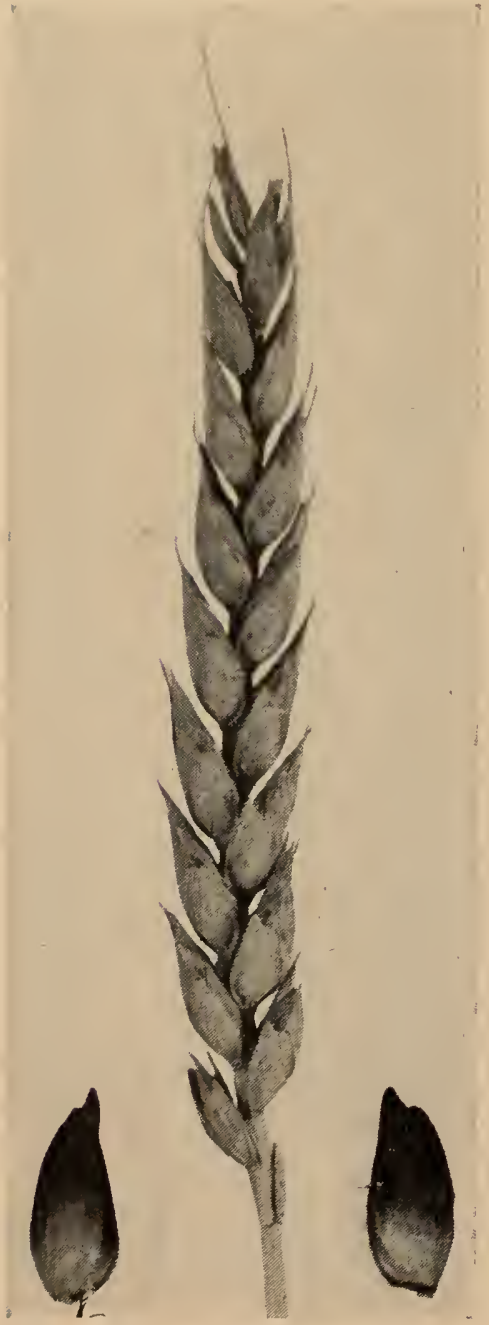

Aurore

C.A.N. 1218 the latter variety; susceptible to rust and smut; not specially inclined to shatter.

Milling and Baking Qualities: Aurore produces a relatively poor quality flour for bread-making purposes, being low in baking strength and yellow in color.

Status AND Distribution: A fair yielder, especially in the East, but its poor quality prevented its becoming widely distributed. It is not being grown commercially. 


\section{Canus}

(C.A.N. 1260)

Origin: Canus came from a cross made in 1918 at the University of Minnesota between Marquis, a spring wheat, and Kanred, a winter wheat. The selection was isolated at the University of Alberta, Edmonton, by Dr. O. S.

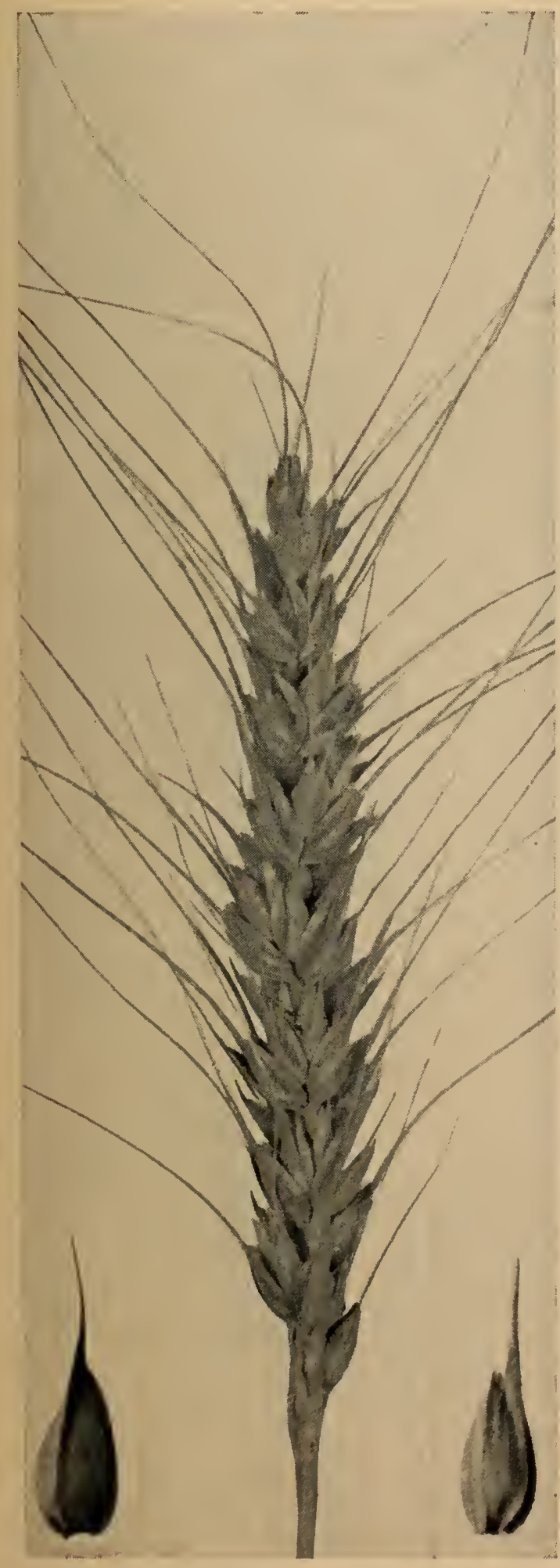

Canus

C.A. N. 1260
Aamodt in 1929, largely because of its resistance to root rots and covered smut.

Description: Head strongly bearded, fusiform and mid-dense; chaff white and smooth; beaks acute, $\frac{1{ }^{\prime \prime}}{4}-\frac{3}{8}{ }^{\prime \prime}$ in length; shoulder narrow with tendency toward elevation; kernels red, hard and more or less oblong; straw strong of medium length and white in color; kernel is held tightly by the chaff; matures about the same time as Marquis; susceptible to stem rust but highly resistant to covered smut and root rot, and relatively resistant to spring frost in the seedling stage.

Milling and Baking Qualities: Canus resembles Reliance in being higher than Marquis in bushel weight and flour yield but slightly lower in protein content and in baking strength. The flour is less creamy than is that from Marquis.

Status and Distribution: Canus appears to be well adapted to the drier areas of south-central and eastern Alberta, and the west-central part of Saskatchewan. It is not grown to any extent at present. 


\section{Cascade}

(C.A.N. 3593)

(Not recommended for the Prairie Provinces)

(ORIGIN: Arose from a cross made by the Cereal Crops Division, Central Experimental Farm, Ottawa in 1936 between $\left(\frac{\text { Quality A } \times \text { Pacific Bluestem }}{\text { C 26-59.2D }}\right)$ $\times$ Onas.

Description: Head medium to long and beardless; chaff smooth and white; straw medium long and strong; beaks short to wanting, wide and acute; shoulders wide obliquely square; kernels white and square; crease medium wide and deep; cheeks rounded; midseason maturity.

Cascade is moderately resistant to stem rust and mildew, moderately resistant to leaf rust and loose smut and moderately susceptible to bunt.

Milling and Baking Qualities: Cascade is a soft to semi-hard white wheat variety. Its quality is not well suited for either pastry or bread flour purposes. It is grown chiefly for feed.

Status and Distribution: This variety has been an outstanding yielder in Eastern Canada and on Vancouver Island. Its fine appearance and good disease resistance has been a factor in its popularity in areas where bread wheats are not commonly grown. In poor harvest seasons, Cascade suffer's from sprouting in the stook and may produce a poor looking sample of wheat under these conditions.

\footnotetext{
CASCADE
}

C.A.N. 3593 


\section{Ceres}

(C.A.N. 1263)

Origin: This variety originated from a cross between Kota and Marquis, made at the North Dakota Experiment Station in 1918. It was introduced into Canada for trial by the Experimental Farm at Brandon, Manitoba, in 1924, from which Farm it later was made available for trial by farmers.

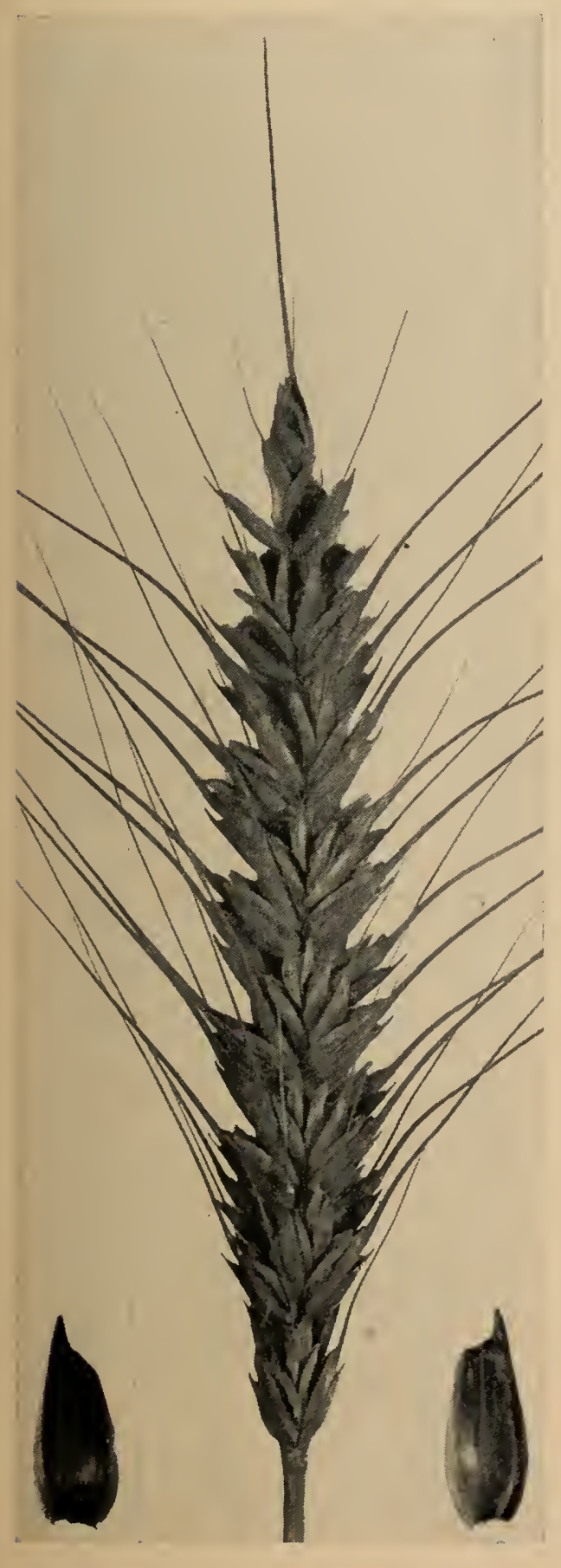

Ceres

C.A.N. 1263

Description: Bearded, chaff white and smooth, bearing slightly inturned beaks which are broadened at the base and which vary considerably in length from $\frac{11}{8}$ to $\frac{1}{2}$ "; kernels red but very susceptible to bleaching; straw not quite so strong as Marquis but of same length; ripens slightly ahead of Marquis and frequently excels it in yield of grain. Is more resistant than Marquis to the common forms of stem rust but is not capable of withstanding a severe epidemic such as that of 1935. It is very susceptible to leaf rust and smut.

Milling and Baking Qualities: Ceres is a high quality spring wheat variety and is classed with Marquis in this respect. It is noted for the ability of its flour to absorb water.

Status and Distribution: Following its introduction, Ceres gained rapidly in popularity until 1935 when the severe rust epidemic of that year spelled its doom. Like Marquis and other varieties susceptible to stem rust, it has practically disappeared from cultivation. 


\section{Chinook}

(C.A.N. 3744)

Origix: Chinook was developed from the cross Thatcher $\times$ S615-11, made at the Cereal Crops Division, Ottawa, in 1938. Thatcher is high yielding, fairly resistant to drought, resistant to most races of stem rust, except $15 \mathrm{~B}$ and with good milling and baking quality. S615-11 is resistant to sawfly, susceptible to most diseases and inferior in bread making quality. Early generation material was grown at the Experimental Farm, Swift Current, Sask., and the final testing completed by the Laboratory of Cereal Breeding, Experimental Farm, Lethbridge, Alta. Chinook resulted from an F7 line first grown in 1943, and licensed and accepted for registered status in 1952. Its high resistance to wheat stem sawfly attack, its drought resistance and good milling qualities make it a suitable variety for the drier areas of Alberta and Saskatchewan.

Description: Head fusiform, mid-long with short apical awns; chaff smooth and white; beaks mid-wide and acute; shoulders square; kernels red, short to mid-long, ovate; straw pithy under most conditions; mid-long; matures with Rescue and is three days ahead of Marquis. Chinook is resistant to most races of stem rust, moderately susceptible to $15 \mathrm{~B}$; resistant to head discoloration; moderately resistant to root rot, bunt and loose smut and susceptible to leaf rust.

Milling and Baking Qualities: Chinook is considered equal to Marquis in milling and baking characteristics and eligible for all Manitoba Northern Grades.

Status AND Distribution: About 8,000 bushels of Chinook were made available to farmers in Alberta and Saskatchewan in 1953. By 1955 Chinook became the third ranking variety in Alberta in point of acreage with $7 \cdot 3$ per cent compared with $53 \cdot 6$ per cent for Thatcher and $12 \cdot 9$ per cent for Saunders. About 3.4 per cent of the Saskatchewan acreage was sown to Chinook in 1955.

Chinook

C.A.N. 3744 


\section{Coronation}

(C.A.N. 1914)

Origin: From a cross between Pentad and Marquis made by the Cereal Crops Division staff located at the Laboratory of Cereal Breeding, Winnipeg, Man.

Description: This variety matures in about the same length of time as Marquis, has bearded heads with awns which are usually quite stiff and spreading and about three to four inches in length. The head is fusiform and mid-dense, and varies from erect to inclined. The glumes are glabrous (smooth) white to

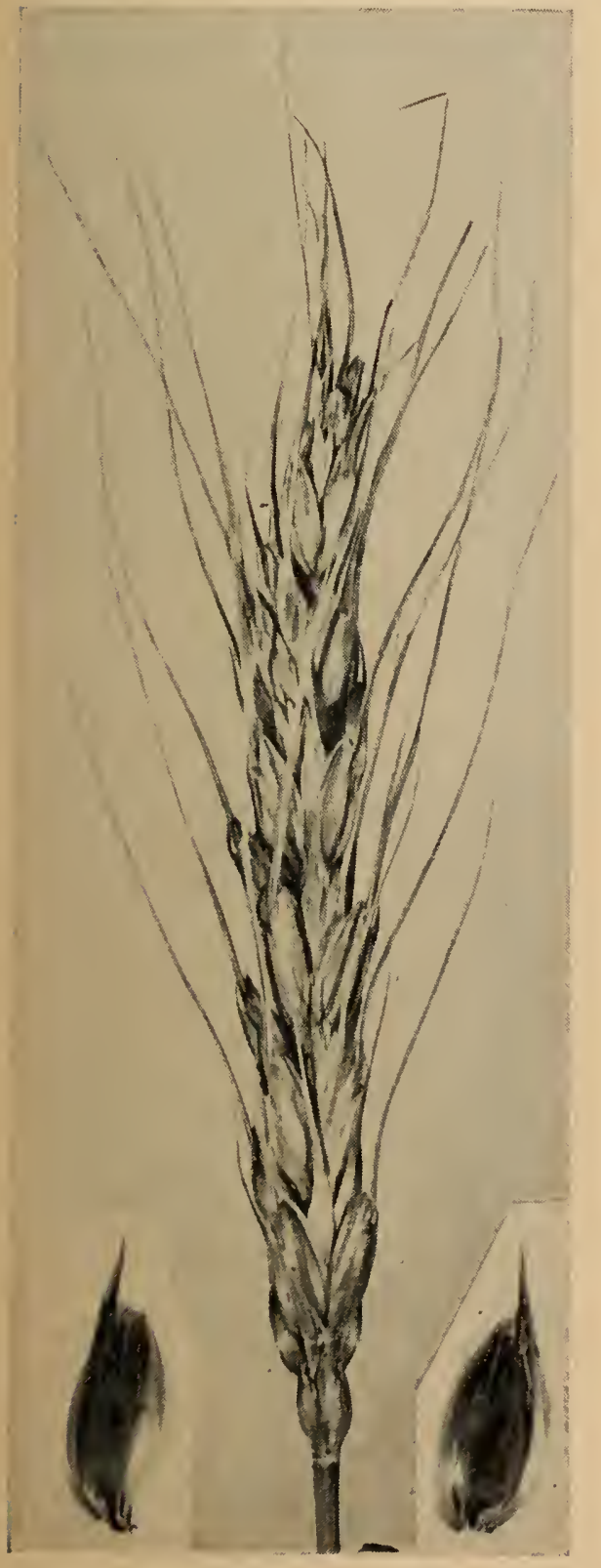

Coronation

C.A.N. 1914 yellowish in color (often with dark blotches), mid-long and mid-wide; shoulders narrow to mid-wide and elevated; beaks narrow, about $2 \cdot 4$ $\mathrm{mm}$. in length at center of head but lengthen out towards tip. The kernels are red, hard, mid-long and somewhat elliptical to ovate; crease mid-wide and mid-deep; cheeks angular to rounded; germ mid-sized and brush mid-long to long. This variety was highly resistant both to stem rust and leaf rust when first introduced, moderately resistant to loose smut but moderately susceptible to bunt.

Milling and Baking Qualities: Milling tests indicate that Coronation during the conditioning or tempering process, takes up water more slowly and requires more of it in order to reach optimum milling condition than do varieties like Marquis. The flour, on the other hand, takes up less water and the dough slackens off more quickly than does that of Marquis. It is, therefore, considered to be inferior to Marquis in quality.

Status and Distribution: Since Coronation is not admitted to the Manitoba Northern grades, it is not grown in Western Canada. In Eastern Canada, however, the variety gave a good account of itself for several years and is still grown to some extent. 


\section{Early Red Fife (Ottawa 16)}

(C.A.N. 1288)

() RIGIN: Farly Red Fife is a pure line selection made at the Central Experimontal Farm, Ottawa, in 1903 from Ordinary Red Fife. It was selected on account of its carliness, ripening as it does from one to three days ahead of its parent.

DEscripton: Head rather long and dense with tendency toward a "club" tip; beardless except for a few short apical awns; chaff white, smooth and quite characteristic in that the keel is usually curved and the

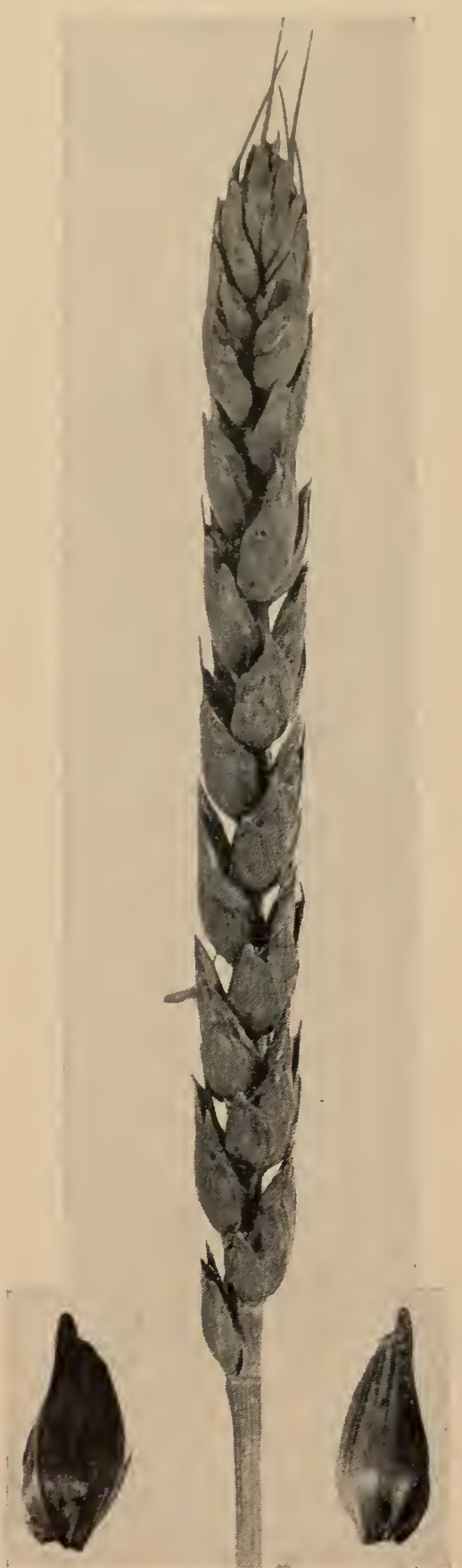

EARLy Red Fife Otr. 16 C.A.N. 1288 shoulders either very narrow or wanting; beaks heavier with less acute tips than in Marquis and more curved especially towards the apex of head; kernels red and rather large; maturing under ordinary conditions, two or three days later than Marquis; straw rather longer than Marquis but of similar strength; very susceptible to stem rust and shatters readily.

Milling and Baking Qualities: Early Red Fife is not quite equal to Marquis in baking strength.

Status AND Distribution: This variety, at one time, had quite a widespread distribution especially in Western Canada. A fair yielder under most conditions but, on account, chiefly, of its susceptibility to rust and shattering, it has practically disappeared from use. 


\section{Federation}

(C.A.N. 1674)

OrIGIN: Obtained from a cross made in New South Wales by Wm. Farrer, Australian wheat breeder, between Yandilla King and Purple Straw.

Description: Head beardless and practically devoid of apical awns; chaff smooth and brown; straw yellow and fairly strong; kernels short but broad, white, and soft in texture.

Milling and Baking Qualities: Federation is a soft white spring wheat variety suitable for pastry flour purposes. The flour is high in yellow pigment.

Status And Distribution: Federation was introduced into North American agriculture during the period between 1914 and 1920 . While it gave promise of becoming a good combine wheat it was never grown commercially to any extent in Canada.

Federation

C.A.N. 1674 


\section{Garnet (Ottawa 652)}

(C.A.N. 1316)

Origin: This variety is a result of a cross made at the Central Experimental Farm, Ottawa, in 1905, between the two Ottawa varieties Preston A. X Riga M.

1) Escription: Head lax and bald except for a few short tip awns; chaff white, smooth, long and soft in texture; beak very fine and sharp, about $\frac{1}{8}$ " in length, usually longer, thinner and sharper than Marquis; straw white and of good length but not so strong as Reward; matures usually from one to three days earlier than Reward; the grain, which is usually longer and thinner than the latter variety, ripens and

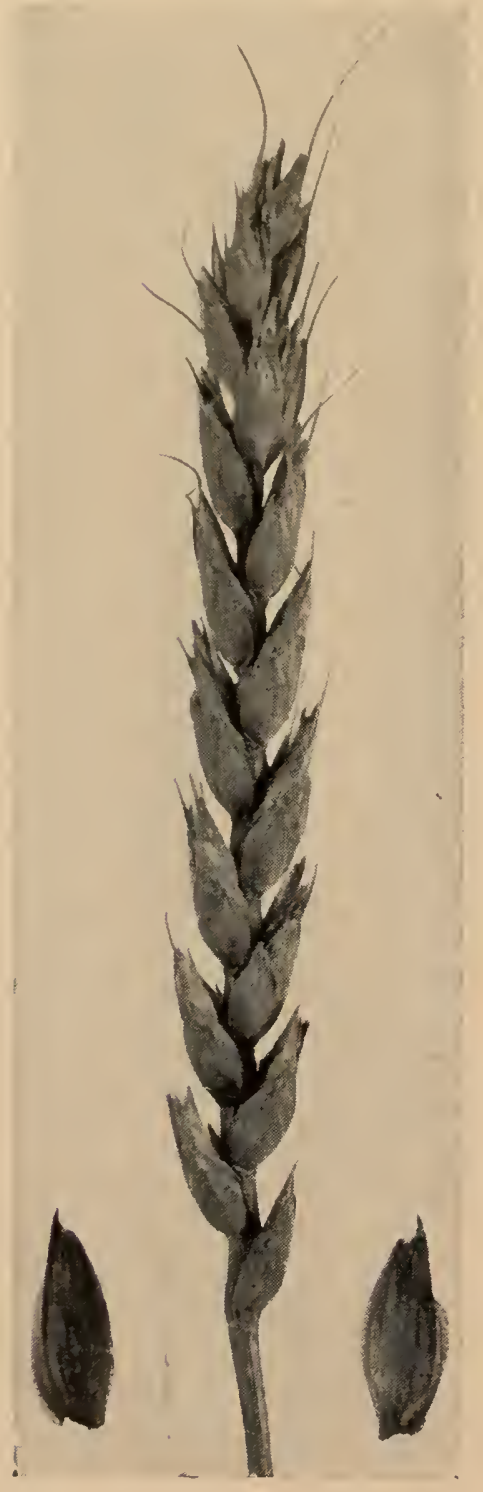
colors well in stook; very susceptible to rust but highly resistant to smut; shatters rather readily. The germ is set in the kernel at a very oblique angle.

Milling and Baking Qualities: Garnet requires different tempering or conditioning conditions than Marquis for best results in milling. Judging by its lower protein content, its lower loaf volume and its shorter dough characteristics it is inferior to Marquis in baking quality. Garnet flour is high in yellow pigment.

Status and Distribution: Since its distribution in the spring of 1926, Garnet enjoyed for some time an important place among the leading wheat varieties in those sections where early frosts are most feared. Garnet was placed in special grades in 1936 which reduced its popularity. In $1955,3 \cdot 7$ per cent of the wheat acreage in Alberta and $0 \cdot 2$ per cent of the Saskatchewan wheat acreage were sown to this variety.

Garnet Ott. 652

C.A.N. 1316 


\section{Hard Red Calcutta}

\section{(C.A.N. 1332)}

Origin: This variety was brought into Canada sometime between 1886-1893 from India as a commercial sample of wheat and was very likely a mixed lot of seed, since at least two distinct forms are recognized.

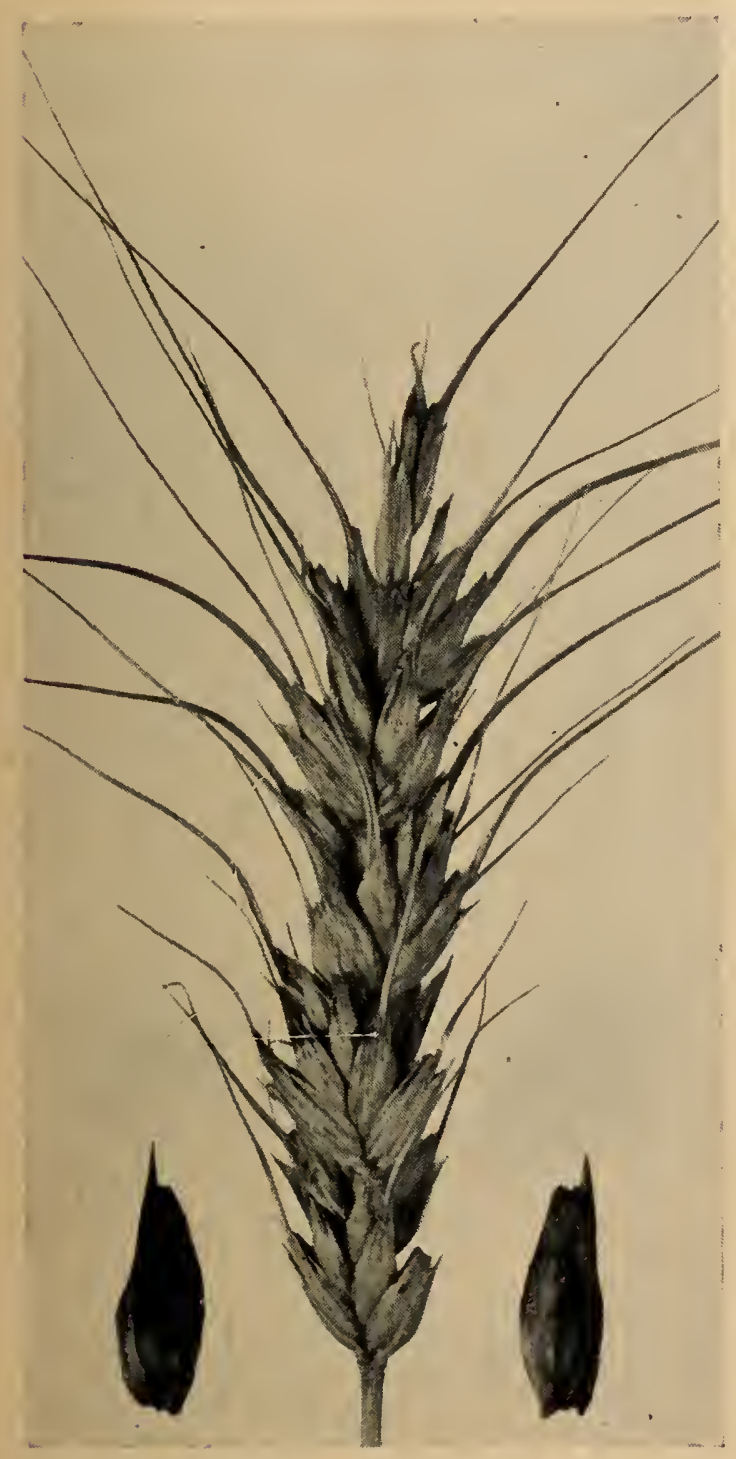

Hard Red Calcutta

C.A.N. 1332

Description: Head bearded; chaff smooth and yellow; kernels red and of midseason maturity; straw white and strong.

Status and Distribution: This wheat was never grown commercially in Canada. The description given is only of historical interest, this variety being one of the parents of Marquis. 


\title{
Huron (Ottawa 3)
}

\author{
(C.A.N. 1344)
}

\section{(Recommended for Eastern Canada)}

Origix: The result of a cross made at Ottawa in 1888 between White Fife and Ladoga.

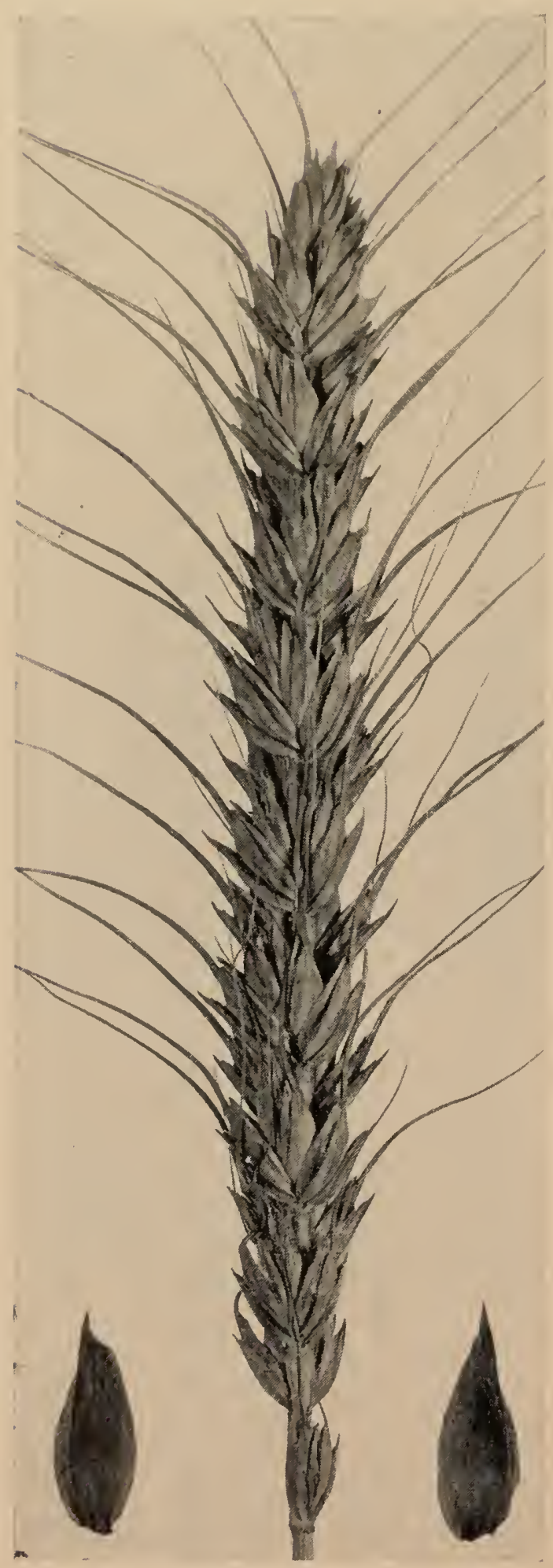

HuRON OTT. 3

C.A.N. 1344

Description: Head large and strongly bearded; chaff red and smooth with sharp beaks varying from $\frac{1}{8}$ " to $\frac{1}{4}^{\prime \prime}$ in length; kernels longer than Marquis but about the same color; matures about with Marquis and is noted for its good yield; straw long and exceptionally stiff; susceptible to rust and smut; threshes easily but does not shatter unduly.

Milling and Baking Qualities: Huron mills readily into a flour which usually is more yellow than that of Marquis and lower in baking strength. For these reasons it is considered inferior to Marquis in bread-making qualities.

Status and Distribution: Huron was once one of the most widely grown varieties in eastern Ontario, Quebec, and the Maritime Provinces, but its supremacy was challenged when the rust resistant varieties, Coronation, Cascade, and Acadia were introduced. This variety is still found growing in parts of Quebec and the Maritime Provinces but only in small isolated stands. 


\section{Ladoga}

(C.A.N. 1386)

OrIGIN: In 1886, Dr. Wm. Saunders obtained for trial in Canada varieties of wheat from all parts of the world with the hope that he might find one capable of ripening earlier than Old Red Fife and which would also be satisfactory from the standpoint of yield and quality. One of the most promising varieties included

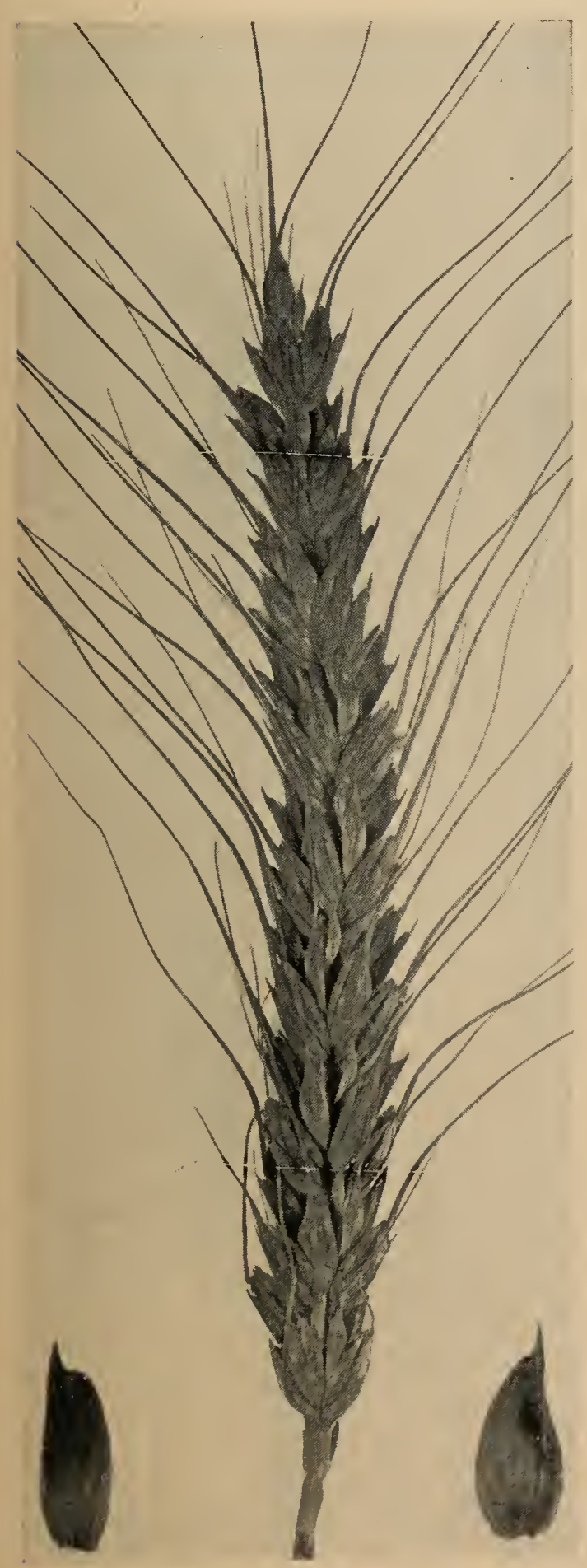

LADOGA

C.A.N. 1386 in this collection was one obtained from near Lake Ladoga in Russia, latitude $60^{\circ}$ N. This was named Ladoga.

Description: Head bearded; chaff brown and smooth; kernels dark red, medium sized and hard in texture; the crease is usually angular and mid-deep; matures about 10 days earlier than Red Fife; the beaks longer than those of Huron and varying from 1 to $5 \mathrm{~mm}$. in length.

Milling And Baking Qualities: Ladoga mills into a flour of rather low baking strength. Its flour is high in yellow pigment.

Status and Distribution: A distribution was made of this variety to over 700 farmers in the Prairie Provinces from 1888 to 1893 . Its chief claim to a place was based on its ability to mature about a week earlier than Red Fife which was then commonly grown. Tests, however, proved that this variety had poor milling qualities and its further distribution was discouraged. It is seldom found growing at the present time although sometimes found in mixtures. It was used quite extensively as a parent in breeding work in the early days. 


\section{Lake (C.T. 918)}

(C.A.N. 3729)

Origix: Lake was developed from the cross Regent $\times$ Canus made at the Experimental Farm, Scott, Saskatchewan, in 1942. Regent is a hard red spring wheat of good milling and baking quality. Canus is resistant to bunt, and possesses good tolerance to dry growing conditions. Lake resulted from a bulked F6 line grown in 1947. It possesses good drought resistance, is resistant to bunt, has good milling qualities, and is suitable for growing in the drier areas of Saskatchewan and Alberta. Licensed and accepted for registered status in 1954.

Description: Head fusiform, with long apical awns; chaff white and pubescent; beaks short, mid-wide and acute; shoulders mid-wide, square to sloping; kernels, medium sized, red and ovate; resistant to most forms of stem rust, but susceptible to $15 \mathrm{~B}$ and to leaf rust; resistant to bunt but moderately susceptible to loose smut.

Milling and Baking Qualities: Lake is considered equal to Marquis in all essential milling and baking characteristics.

Status And Distribution: 1200 bushels of Lake were distributed in 8-bushel lots and foundation seed went out to elite growers in 1954. It was grown largely in northwestern Saskatchewan in 1955. 
Lee

\section{(C.A.N. 3751)}

Origin: This variety was developed at the University of Minnesota in cooperation with the U.S.D.A. from the cross Hope $\times$ Timstein* made in 1939 . It was first received in Canada for testing in 1947 under the name Hope $\times$ Timstein Minn. 2776. It was licensed in March 1950 and accepted for registered status in the same year. Lee outyields the standard varieties in areas where leaf rust is an important factor but not in other areas, and excels the Redman and Thatcher varieties in leaf rust resistance.

Description: Head bearded, fusiform; chaff smooth and white; kernels ovate, medium sized and red. The straw is strong and medium long; matures in mid-season. Lee is resistant to stem rust, leaf rust and root rot, but moderately susceptible to loose smut and susceptible to bunt.

Milling and Baking Qualities: Lee is classed as a high quality wheat variety. It is usually higher than Marquis in wheat protein and in dough water absorption.

Status And Distribution: In 1955, the estimated acreage sown to Lee was 312,670 acres in Manitoba and 832,950 acres in Saskatchewan.

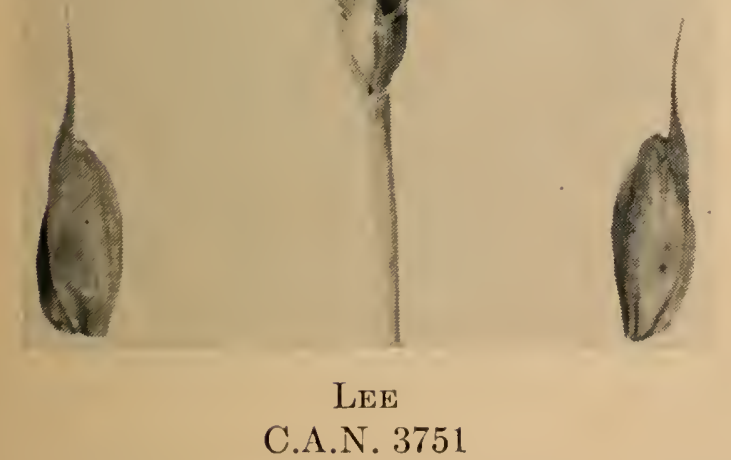

*That Timstein was one of the parents of Lee is now questioned. 


\section{Lemhi}

\section{(C.A.N. 3720)}

() RIGIx: I.emhi was developed through co-operative investigations by staff members of the Idaho Agricultural Experiment Station and the Division of Cereal Crops and Diseases, United States Department of Agriculture, at the Aberdeen substation, from a cross between Federation and Dicklow made in 1921. The hybrid progeny was grown in bulk until 1927 when head selections were made. The selection was multiplied and then grown in a uniform irrigated nursery in the western

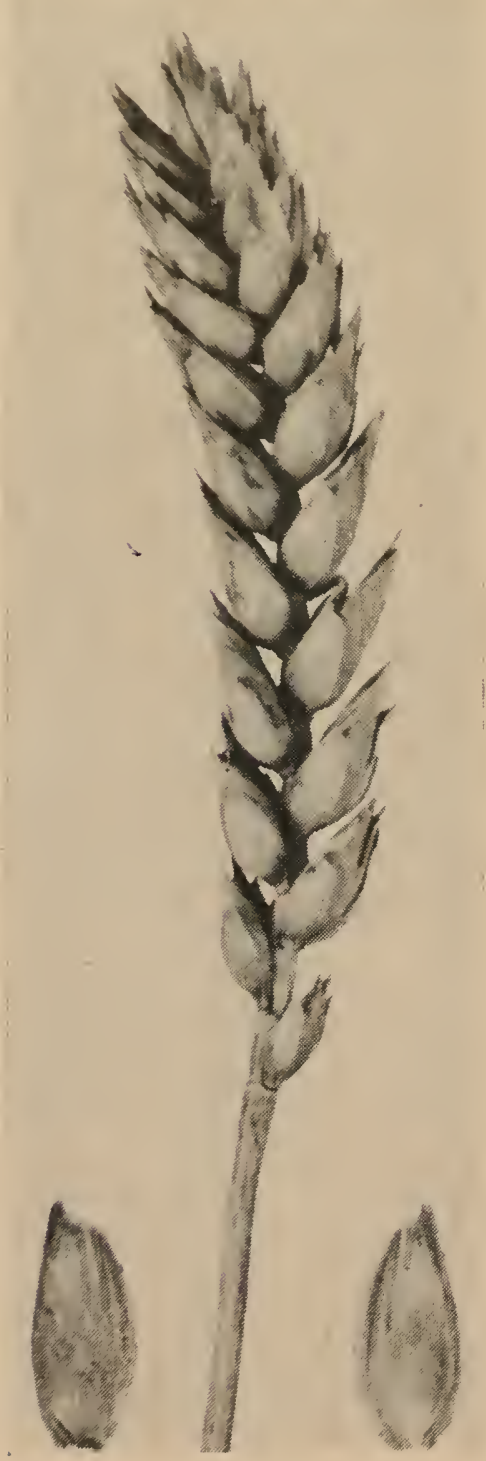

LEMHi

C.A.N. 3720 region in 1931. It continued to show promise and was named in 1935.

Description: Head awnless, dense and erect to inclined; chaff white and glabrous; shoulders midwide and oblique; beaks wide and obtuse; kernels white, short to mid-long; early to midseason in maturity; straw short and moderately stiff. Lemhi is susceptible to leaf rust, stem rust and to mildew.

Milling and Baking Qualities: Lemhi is a good soft white spring wheat variety for use in the production of cake and pastry flour.

Status And Distribution: In Canada, Lemhi is grown only on the irrigated areas of southern Alberta, where it yields well and produces a very satisfactory soft wheat. 


\section{Marquis (Ottawa 15)}

(C.A.N. 1396)

Origin: Marquis is a descendant of a cross made in 1892 by officials of the Central Experimental Farm, Ottawa, Ontario, between an early ripening wheat, obtained from India under the name of Hard Red Calcutta, and Red Fife. It was selected in 1903 by the late Sir Charles E. Saunders, then Dominion Cerealist, and was first sent to Western Canada for trial on branch farms in 1907.

Description: Head beardless; chaff white and smooth and held more closely than in Red Fife; kernels red and hard; medium early maturity; straw stiff and of medium length; susceptible to rust (Puccinia graminis tritici).

Marquis resembles Red Fife quite closely, being distinguished chiefly by shape and density of head, "spread" of tip awns, shape of glumes and length of "beak". It also requires from a week to ten days less than Red Fife to ripen.

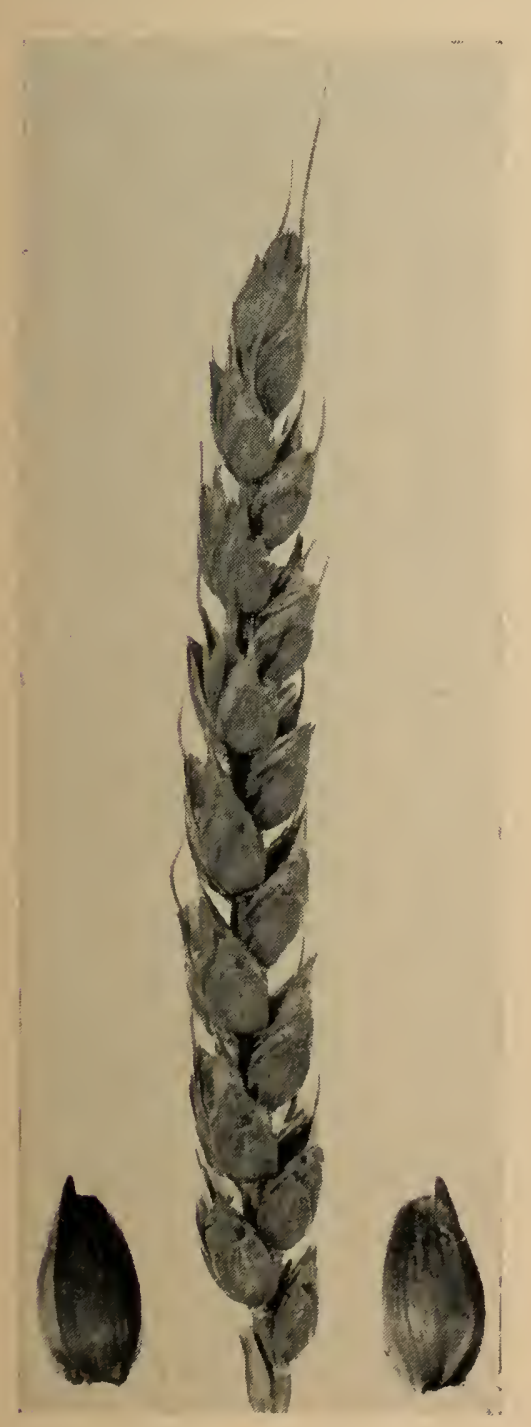

Marquis OTt. 15

C.A.N. 1396

Milling and Baning Qualities: When grown under favorable conditions in Western Canada Marquis mills freely into a flour of good color which in turn produces strong elastic doughs of the best type not only for baking into "well piled" loaves but for blending with weaker wheats.

For many years, this variety has been taken as the standard of comparison for other varieties to meet or excel before they may be considered eligible to be graded into the top Manitoba Northern grades of commercial wheat.

Status and Distribution: The ability of Marquis to mature several days earlier and to resist lodging better than Red Fife, coupled with its superior yielding capacity, caused it to supersede the latter variety with amazing rapidity until it occupied by 1928, about 90 per cent of the area devoted to spring wheat in Western Canada. Since that time Marquis has been replaced by rust-resistant and earlier maturing varieties until by 1955 it has all but disappeared in Manitoba and only 0.8 per cent of the wheat acreage in Saskatchewan and $3 \cdot 5$ per cent in Alberta were devoted to this variety. 


\section{Prelude (Ottawa 135)}

(C.A.N. 1481)

OrIGIN: This variety originated from a cross between Downy Gehun and Fraser, made at the Central Experimental Farm, Ottawa, in 1903.

Description: Head of medium size, bearded; awns quite dark in color especially toward the base; chaff yellowish and hairy; kernels dark red in color and of exceptionally high weight per bushel; threshes very easily; straw short and fine and of good strength. This is the earliest of the well-known wheats in Canada.

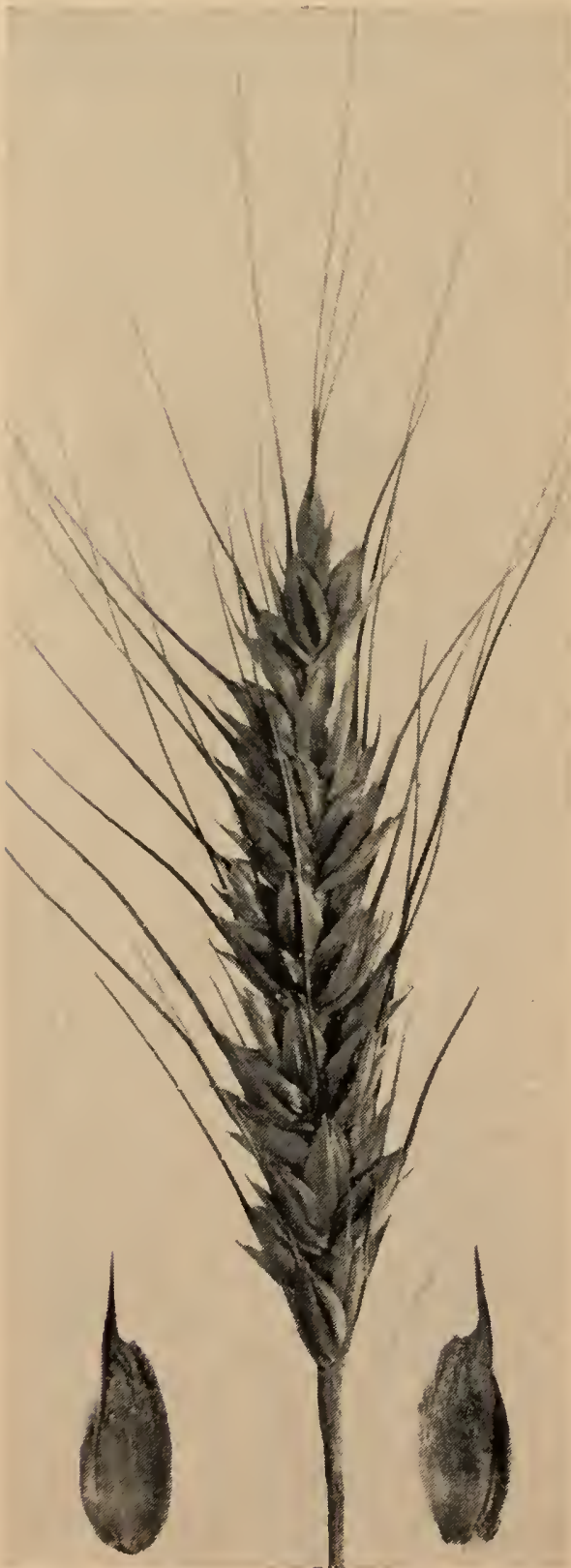

Prelude

C.A.N. 1481
Milling and Baking Qualities: While usually much higher in protein content than Marquis, it is not quite its equal in baking strength and flour color.

Status and Distribution: This variety has not been grown extensively in Canada, being confined chiefly to the more northerly areas where extreme earliness is a prime requisite. Even here, it is found very rarely at the present time, its relatively low yields accounting largely for its unpopularity. 


\section{Preston (Ottawa 4)}

(C.A.N. 1482)

Origin: Preston came from a cross made in 1888 by the late Dr. Wm. Saunders, Ottawa, between Ladoga and Red Fife.

Description: Head strongly bearded; chaff white and smooth; beaks sharp, about $\frac{1}{8}$ " in length; kernels red and hard; straw of medium length and strength

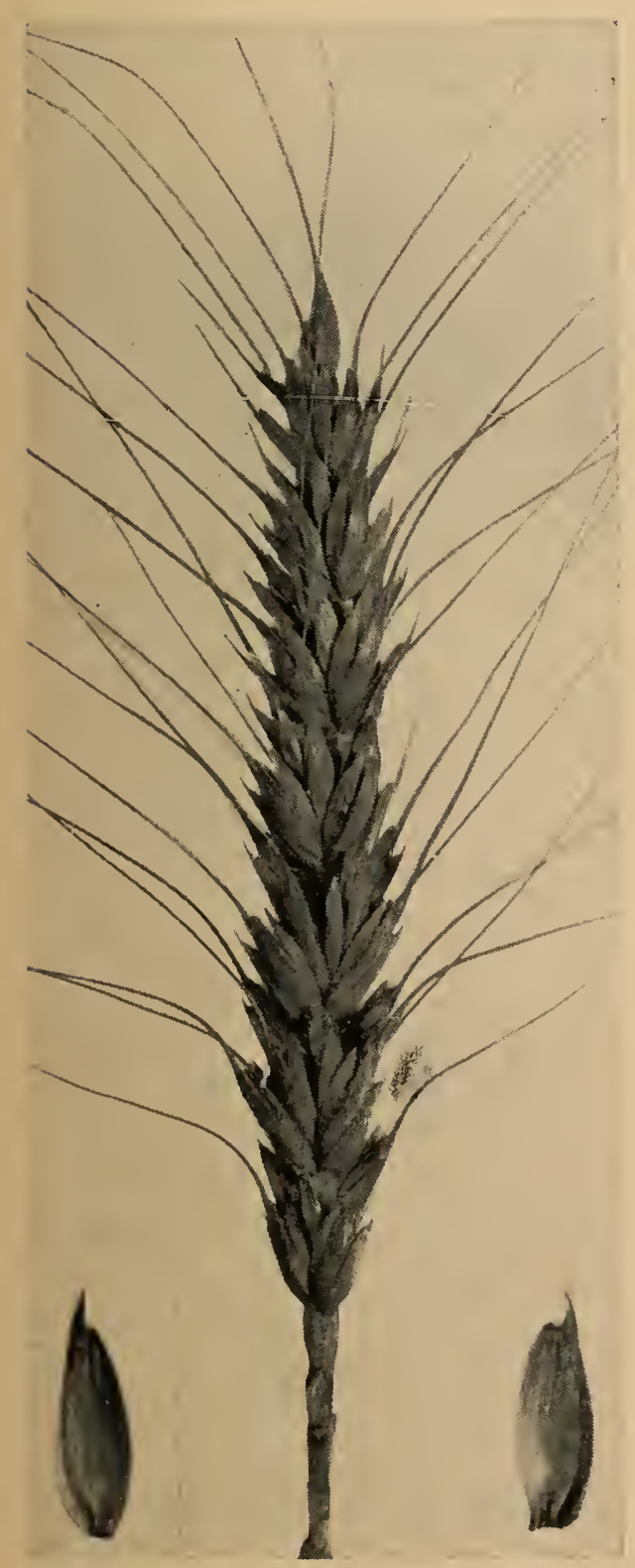

Preston

C.A.N. 1482 and generally white in color although, under certain conditions, exhibits a reddish purple coloration around the lower nodes; grain held rather loosely in the head; matures about the same time as Marquis.

Milling and Baking Qualities: Preston is inferior to Marquis in baking strength and decidedly more yellow in flour color.

Status and Distribution: By 1895, this variety had obtained a fairly wide popularity and for several years was grown extensively in both Canada and the United States. Its susceptibility to stem rust and its lack of the desired milling qualities have been responsible in large part for its replacement in Canada by better varieties. 


\section{Red Bobs 222}

(C.A.N. 1637)

()Ricix: A reselection of Early Triumph made at the University of Alberta, Edmonton, and first distributed about 1925.

1)Escripton: Head absolutely bald, oblong, and somewhat dense, chaff smooth and white; kernels red but inclined to "go starchy" under certain conditions; straw of medium length and of good strength; very susceptible to rust and smut.

Milling and Baking Qualities: Red Bobs 222 is classed as a fair quality wheat varicty. It mills very freely but is usually below Marquis in wheat protein and in baking strength.

Status and Distribution: The distribution of this particular selection has been confined chiefly to Alberta, in which province it gained considerable popularity especially in the southern areas where the combine harvester, to which it seems well adapted, is largely used. In 1952, Red Bobs was excluded from grading higher than Manitoba 3 Northern and since then the acreage seeded to this variety has declined. In 1955, only 5 per cent of the Alberta wheat acreage was sedeed to Red Bobs.

Red Bobs 222

C.A.N. 1637 


\section{Red Fife}

(C.A.N. 1515)

ORIGIN: Red Fife was introduced into Canada through a shipment of wheat originating in Danzig, Germany, a sample of which was sent to Mr. David Fife, of Peterboro, Ontario, by a friend in Glasgow in 1842. This sample, sown in the spring, turned out to be almost all winter wheat, but a few kernels proved to be typical spring wheat and their progeny was saved. These were the progenitors of Red Fife.

Description: Head beardless except for a few tip awns, one of which is considerably longer than the others; chaff white and smooth; kernels red and hard; glumes bearing more sloping shoulders and shorter beaks than those of Marquis; straw of fair length and strength; late maturing but productive; very susceptible to stem rust and bunt.

Milling and Baking Qualities: Red Fife is the equal of Marquis in all essential milling and baking characteristics.

Status and Distribution: This variety, chiefly because of its late maturity and susceptibility to rust, quickly fell into the discard with the introduction of Marquis. It is now seldom found except in mixtures.

\footnotetext{
RED FIFE

C.A.N. 1515
} 


\section{Redman}

\section{(C.A.N. 3633)}

Origix: From a cross between Regent and Canus made in 1934 by the Cereal Crops Division staff located at the Laboratory of Cereal Breeding, Winnipeg, Man.

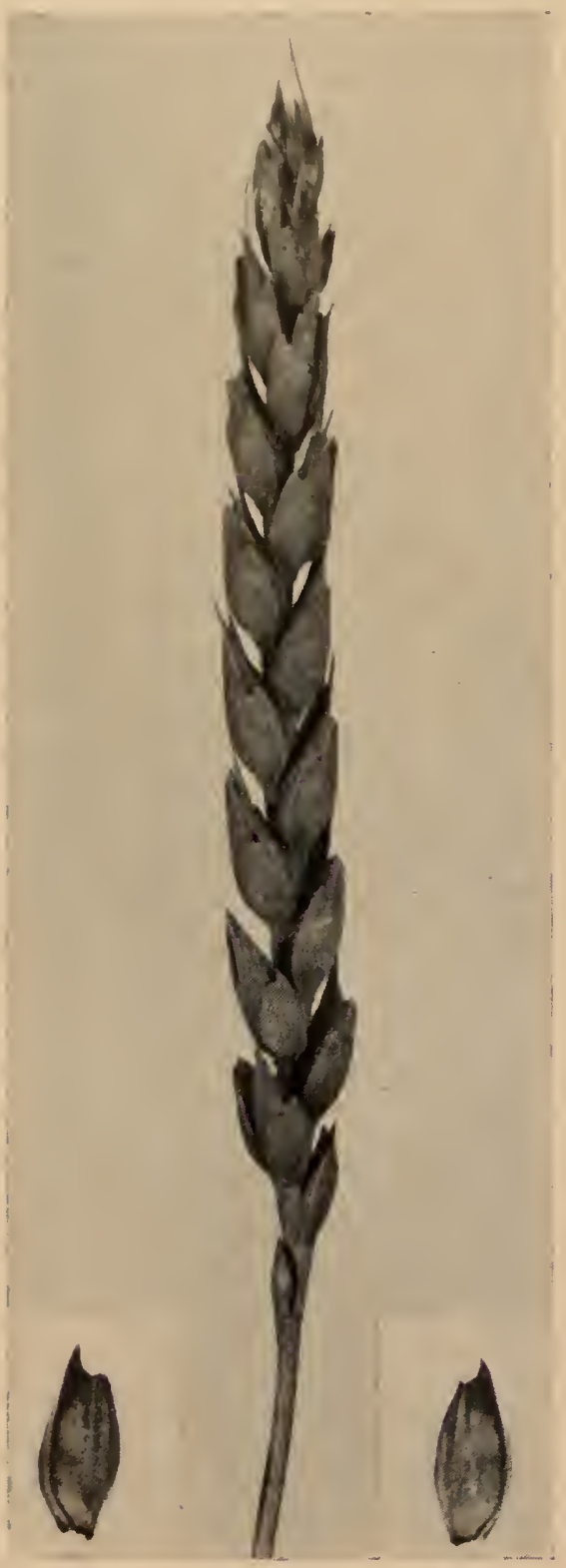

Description: Head beardless with apical awnlets slightly longer than those of Regent. Chaff yellow (somewhat deeper in color than Regent) and smooth. Spikelets almost straight in arrangement, less zigzag than Regent. Straw strong and of same height as Regent. Like Regent in general appearance but with heavier straw and a larger, more rugged head. Kernels dark red in color, rather large and rough in appearance. Matures about a day earlier than Thatcher and a day later than Regent.

In the three years 1943-45 Redman excelled Regent in yield in the three Prairie Provinces and Thatcher in Manitoba. It has yielded slightly less than Thatcher on the average in Saskatchewan and Alberta.

Redman is resistant to most races of stem rust, except $15 \mathrm{~B}$, bunt and black chaff, and somewhat more resistant than Regent to leaf rust, loose smut and root rot.

Milling and Baking Qualities: Redman ranks with Marquis in quality. It mills very freely and produces a flour of good color and of high baking strength.

Status and Distribution: Redman was recommended for license in the spring of 1946 . Approximately 1,000 bushels of seed were increased under control for general distribution in 1947. Since the introduction of the Selkirk wheat, which is resistant to race $15 \mathrm{~B}$ stem rust, the acreage sown to Redman has declined. Manitoba had 9.5 per cent of its wheat acreage sown to Redman in 1955.

REDMAN

C.A.N. 3633 


\section{Regent}

(C.A.N. 1902)

OrIGIN: Obtained from a cross between H-44 and Reward made by Cereal Crops Division staff at the Laboratory of Cereal Breeding, Winnipeg. Prior to 1939 it was known as R.L. 975.1.

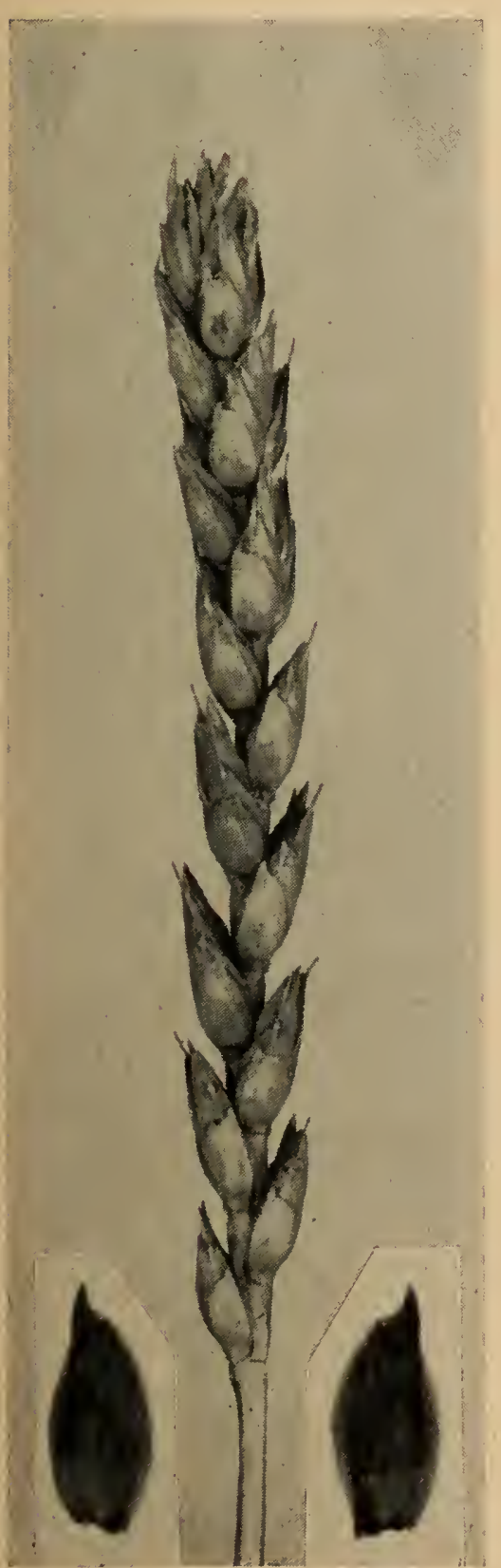

REgent

C.A.N. 1902

Description: Head beardless, chaff white and smooth, mid-dense and inclined to be slightly ragged with a few tip awns; straw medium strong and slightly taller than Thatcher as a rule. Kernels dark red in color, rather large and rough in appearance; matures in about same period of time as Renown and Thatcher, and two or three days ahead of Apex. Regent is resistant to stem rust (other than race $15 \mathrm{~B}$ ), leaf rust and covered smut. It is definitely superior to Apex, Renown and Thatcher in leaf-rust resistance. Regent has been a close competitor of Thatcher from a yield standpoint, but has been slightly higher yielding than either Renown or Apex. In 1938 it out-yielded the other three varieties where leaf rust was prevalent.

Milling and Baking Qualities: Regent is a high quality red spring wheat variety. It is superior to Marquis in wheat protein and in baking strength.

Status and Distribution: Regent was licensed in the spring of 1939. The initial distribution, consisting of approximately 11,000 bushels, was made to farmers chiefly in Manitoba and eastern Saskatchewan. At present, this variety because of its susceptibility to race $15 \mathrm{~B}$ stem rust, has largely been replaced by Selkirk. The acreage devoted to this variety in Manitoba in 1955 declined to $2 \cdot 5$ per cent, where at one time it ran second only to Thatcher. 


\section{Reliance}

\section{C.I. 7370 , Sask. 1851 (C.A.N. 1498)}

Origrx: Reliance was developed by the United States Department of Agriculture in co-operation with the Oregon, California, Montana, North Dakota, and Minnesota Experiment Stations from the cross Kanred $\times$ Marquis made in 1917.

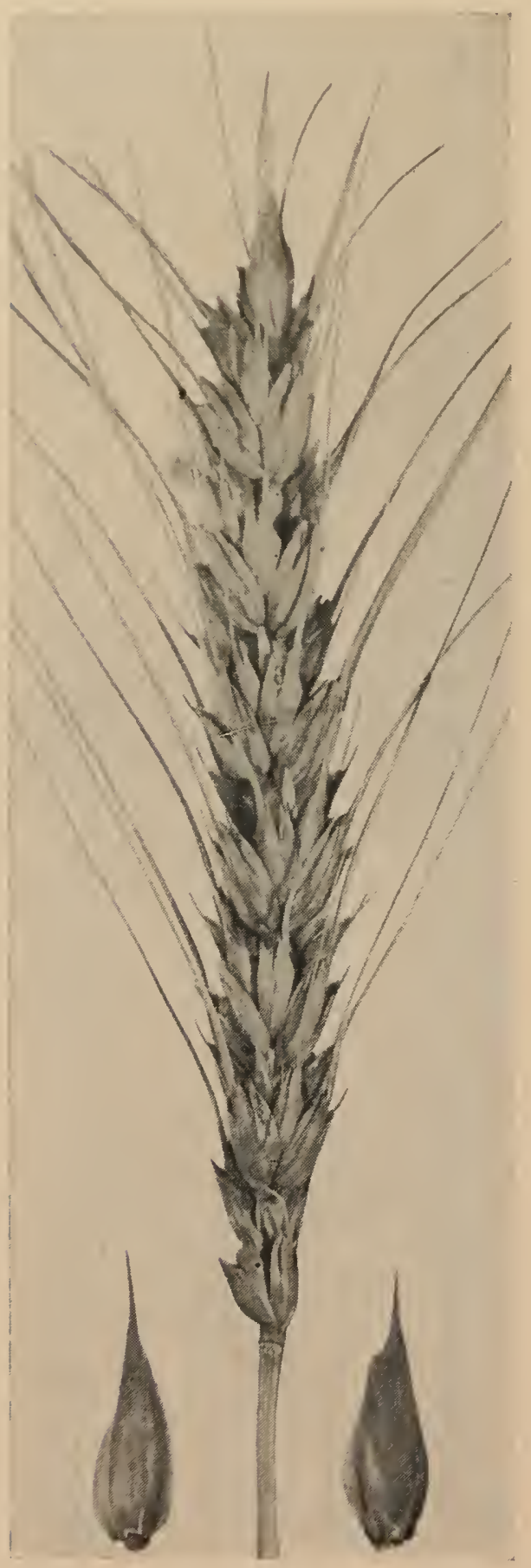

Description: Head bearded; chaff white and smooth; beaks sharp, averaging about $\frac{1}{8}$ " in length; kernels red and hard; straw of medium length, strong and generally white in color; grains held moderately firmly in the head; matures about the same time as Marquis; vigorous in growth and high in yield.

Milling and Baking Qualities: Reliance is usually higher than Marquis in weight per bushel and in flour yield but slightly lower in percentage protein and in baking strength. The flour is slightly yellower than that of Marquis.

Status and Distribution: Recommended first in 1933 by the Saskatchewan Seed Board for trial in southwestern Saskatchewan. On account of its relatively high yielding capacity under drought conditions, this variety became fairly widely distributed although the total acreage occupied remains very small.

Reliance

C.A.N. 1498 


\section{Renfrew}

(C.A.N. 1514)

Origin: This variety was developed by the Department of Agronomy, University of Alberta, in 1918, as a selection out of Marquis.

Description: Head beardless; chaff white and smooth; kernels red and hard; straw very long and quite strong; ripens usually 3 to 5 days later than Marquis; head usually longer and more open than

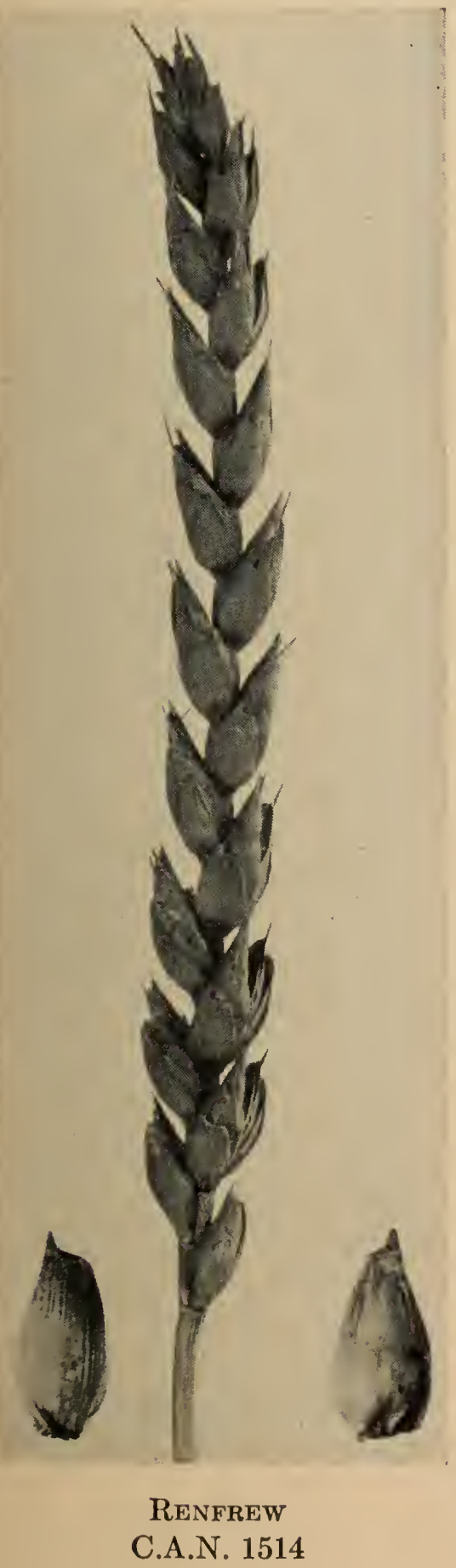
Marquis; glumes long and shoulders square with very short acute beaks.

Milling and Baking Qualities: Renfrew compares favorably with Marquis in all essential milling and baking characteristics.

Status and Distribution: For a few years, this variety was rather popular in parts of Alberta and Saskatchewan but its late maturity has gradually brought about its practical extinction. 


\title{
Renown
}

\author{
(C.A.N. 1856)
}

Origin: From a cross made by the Cereal Crops Division staff located at the Laboratory of Cereal Breeding, Wimnipeg, Man., in 1926, between H-44-24 and Reward.

Description: General shape and size of head fairly similar to that of Marquis but arrangement of spikelets more inclined to be irregular (zigzag) as in the Reward parent; glumes, including shoulders and beaks, very similar to Marquis; kernels more of the Reward type and weighing slightly more than those of Marquis; matures midway between Reward and Marquis at most western points; straw strength essentially in same class as Marquis in most districts but length of straw slightly less; straw frequently takes on a purplish color at maturity. It yielded less than Thatcher in

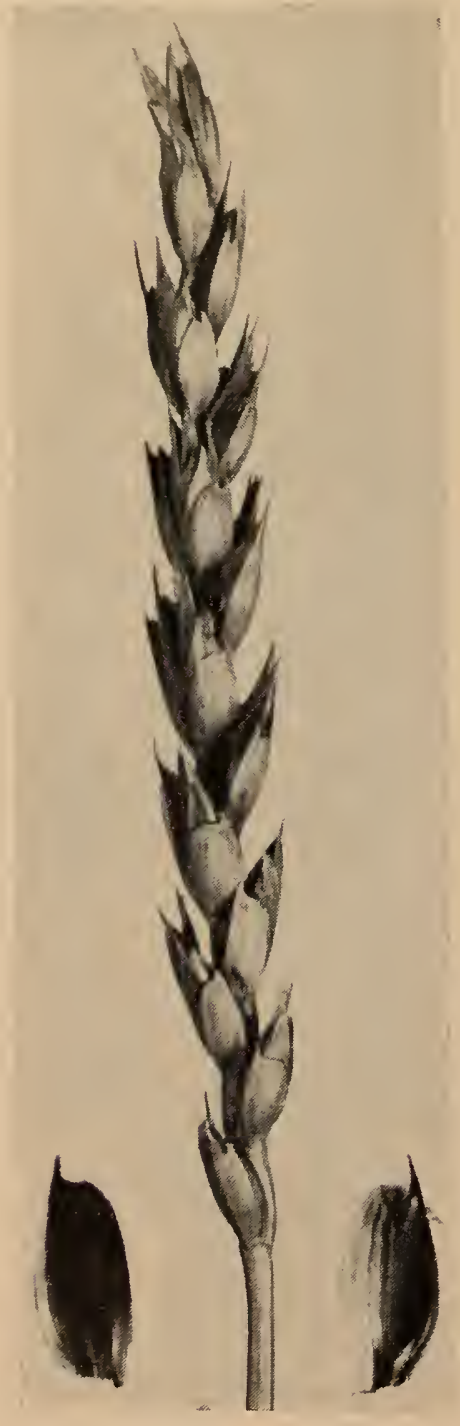

RENOWN

C.A.N. 1856 tests conducted in all three provinces during the five years, 1933-37, and less than Marquis in west-central Saskatchewan and in Alberta where rust does not occur. In 1938, it did better than Thatcher in many sections, owing, presumably, to its greater resistance to leaf rust.

This variety, when first introduced, proved highly resistant to prevailing forms of stem rust and to stinking smut; moderately resistant to loose smut and leaf rust. A selection out of Renown (R.L. 716.6) was made which was resistant to leaf rust and became the basis of all registered seed of this variety.

Milling and Baking Qualities: Renown is a good quality variety and ranks with Marquis in this respect. It has been high in bushel weight and flour yield.

Status and Distribution: The first distribution of this wheat took place in the spring of 1937 when a total of 6,310 bushels went to 1,765 farmers in Manitoba and eastern Saskatchewan. Because of its susceptibility to race $15 \mathrm{~B}$ of stem rust Renown has become practically extinct. 


\section{Rescue}

(C.A.N. 3567)

Origin: Obtained from a cross between Apex and S-615, made in the greenhouse of the Cereal Crops Division, Central Experimental Farm, Ottawa, in February 1938. The resultant population was transferred to the Experimental Farm, Swift Current, Saskatchewan, for exploitation. Here plant breeders in co-operation with the Entomology Division, Science Service, produced Rescue.

Description: Rescue has the distinction of being the first bread wheat to be introduced which is capable of resisting the attacks of the wheat stem sawfly (Cephus cinctus Nort.) to a high degree. General

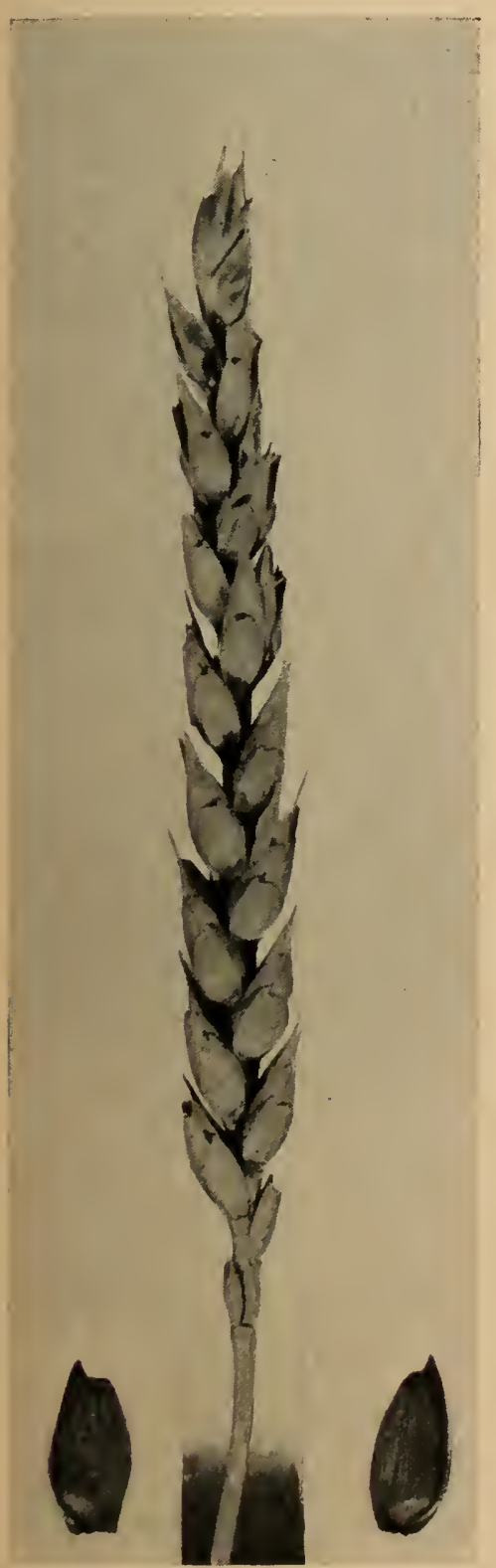

RESCUE

C.A.N. 3567 shape and size of head very similar to Apex; shoulder slightly elevated; kernels larger and brighter than Thatcher with less tendency to bleach; bushel weight heavier. Straw slightly longer than Thatcher and medium strong under conditions in the Great Plains area but definitely weak in Black soil zones. Rescue is slightly later than Thatcher but earlier than Marquis. Resistant to stem rust but susceptible to leaf rust and bunt and moderately susceptible to root rot; easier to thresh than Thatcher but no shattering has been observed in the field. In yielding ability it is somewhat lower than Thatcher but where damage from sawflies is great, it is definitely superior.

Milling and Baking Qualities: Rescue produces a softer and more extensible dough than does Marquis. It is slightly below Marquis in dough water absorption. For these reasons it is considered to be slightly inferior to Marquis.

Status and Distribution: Approximately 7,000 bushels of Rescue were distributed to District Experimental Substations and selected growers in the sawfly area in the spring of 1946. This variety has proved valuable in sawfly areas of southwestern Saskatchewan and southern Alberta, where the acreage sown to this variety in 1955 in Saskatchewan was 11.9 per cent, in Alberta $3 \cdot 9$ per.cent. 


\section{Reward (Ottawa 928)}

(C.A.N. 1509)

ORIGIN: Reward is the result of a cross made in 1912 at the Central Experimental Farm, ()tawa, between Marquis and the very early maturing variety Prelude. It was first released for trial by farmers in 1928.

DEscription: Head rather "ragged" in appearance and bald except for a few short tip awns which are dark in color toward the base; chaff white with a sparse covering of very fine hairs; kernels hard, very plump and dark red when fully ripened but otherwise have a tendency toward a greenish bronze cast which not infrequently degrades the sample; straw medium long and very stiff; suffers less than Marquis from attacks of stem rust; matures five to eight days earlier than Marquis; threshes easier than Marquis but does not shatter readily; quite susceptible to both loose smut and bunt.

Milling and Baking Qualities: Reward is consistently higher than Marquis in bushel weight, wheat protein and loaf volume. Its dough mixing properties are somewhat different from those of Marquis.

Statusand Distribution: Reward enjoys an enviable reputation as an early wheat and as a wheat of unusual quality and weight. Unfortunately, it falls short in yielding ability except in certain more or less restricted areas such as in the Red River Valley and in certain sections of the Park Belt across the north. Since its introduction, it has been a consistent championship winner at the International Hay and Grain Show at Chicago and at other seed exhibitions.

The acreage devoted to this variety has become relatively small.

REWARD

C.A.N. 1509 


\section{Ruby (Ottawa 623)}

(C.A.N. 1511)

OrIGIN: This variety arose from a cross made at the Central Experimental Farm, Ottawa, in 1905 between Downy Riga, an Ottawa-bred variety, and Red Fife D.

Description: Head beardless; chaff whitish-yellow, smooth; kernels dark red, hard and medium to small in size but of good weight per measured bushel; straw purple when ripe; matures earlier than Marquis by seven to ten days; shatters badly.

Milling and Baking Qualities: Ruby compares favorably with Marquis in milling and baking characteristics.

Status And Distribution: Ruby was first distributed in 1917 during World War I when every effort was being made to produce more wheat. For a few years it was widely grown, but was replaced by Garnet and Reward and is rarely found except in mixtures.

\section{RUBY}

C.A.N. 1511 


\section{Saunders}

(C.A.N. 3516)

Origin: Saunders originated as a cross made by Cerealists of the Cereal Crops Division, Central Experimental Farm, Ottawa, in 1938, between an early ripening Brandon hybrid variety, C 26-44.7 (Hope $\times$ Reward) and Thateher. This variety appeared in the Co-operative Test of Wheat Varieties in 1943 to 1946 as C'T 406 and also as 40-31.

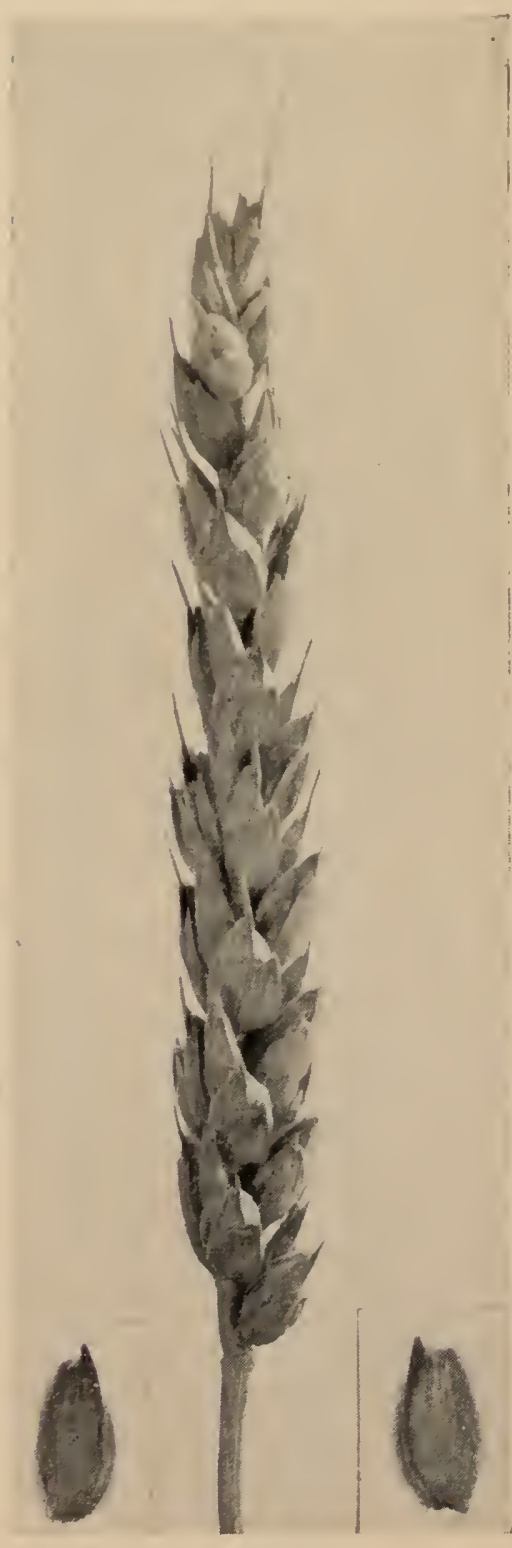

SAUNDERS C.A.N. 3516
It was licensed in 1947, when 210 bushels of seed were available. This was increased and the first distribution to farmers in northern and western Alberta was made in the spring of 1948 , when 5,700 bushels were released. The 1948 crop was estimated at 100,000 bushels.

Description: Head beardless, except for a few tip awns; chaff white and smooth; fusiform, middense; straw strong and slightly shorter than Thatcher as a rule; kernels dark red in color and ovate in shape, closely resembling Marquis in type. It matures one to two days ahead of Thatcher, about five days earlier than Marquis, and about the same time as Garnet. Saunders is moderately resistant to stem rust and loose smut, moderately resistant to bunt, black chaff and root rot, and moderately susceptible to leaf rust, but is definitely superior in the latter respect to Red Bobs and Thatcher. It is not resistant to race $15 \mathrm{~B}$ of stem rust.

Saunders has shown to best advantage in northern Alberta. This variety is not recommended for the plains areas of Saskatchewan and Manitoba but does well in the northern areas of these provinces. In northern Alberta it has outyielded 'Thatcher, which is its nearest competitor and is superior in yield to Marquis, Red Bobs and Redman in those areas.

Milling and Baking Qualities: Saunders is of the same general quality as Marquis and is therefore acceptable for all Manitoba Northern grades.

Status and Distribution: The present status of this variety indicates that it is largely an Alberta variety although small quantities are raised in northern Saskatchewan and Manitoba. In 1949 the crop was estimated at 1.6 million bushels. From 1950 to 1955 , the acreage of Saunders in Alberta jumped from $6 \cdot 7$ per cent to $12 \cdot 9$ per cent. 


\section{Selkirk}

(C.A.N. 3894)

OrIgIN: Developed at the Winnipeg Laboratories by the Rust Area Project Group of the Canada Department of Agriculture. The crosses and backcrosses are (McMurachy $\times$ Exchange) $\times$ Redman $^{3}$, and were made in 1939, 1944, 1945, and 1946. It was licensed and accepted for registered status in 1953. Selkirk is very similar to Redman in appearance.

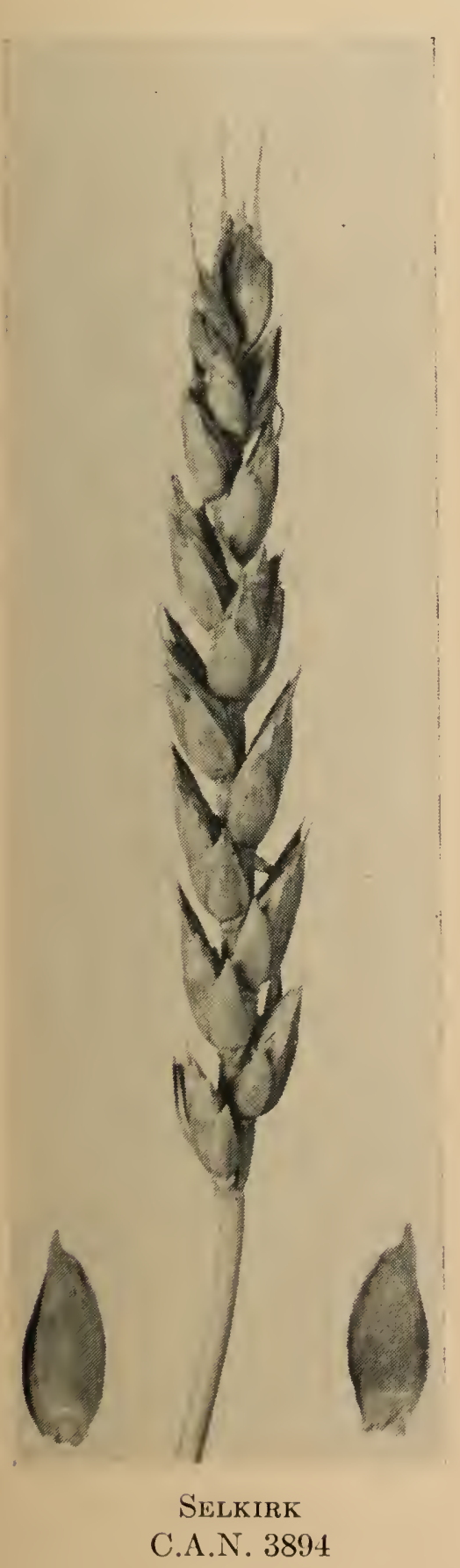

Description: Head beardless, with short apical awns, fusiform, mid-dense, mid-long; chaff smooth, white at maturity ; beaks short, mid-wide, and acute; shoulders mid-wide, sloping to slightly elevated; kernels ovate, mid-long, hard, red; cheeks angular to rounded; brush large, mid-long; germ small. Selkirk is resistant to stem rust, including the prevailing strains of $15 \mathrm{~B}$; moderately resistant to leaf rust; resistant to bunt and loose smut.

Milling and Baking Qualities: Selkirk like Redman mills very freely and gives a high flour yield. It is ranked as equal in quality to Marquis.

Status And Distribution: In 1954, 130,000 bushels of Selkirk were distributed to farmers in the rust area which included Manitoba and that part of Saskatchewan east of the Third Meridian. By 1955, almost 3,300,000 acres of Selkirk were grown in that area, roughly $12 \cdot 8$ per cent of the wheat acreage in Saskatchewan and $64 \cdot 6$ per cent of the wheat acreage in Manitoba. 


\section{Stanley (Ottawa 5)}

(C.A.N. 1536)

ORIGIN: 'This is the result of a cross made at the Central Experimental Farm, Ottawa, Ont., in 1888 between Ladoga and Red Fife. It is, therefore, a sib of Preston.

DESCRIP'TION: Head beardless; chaff red

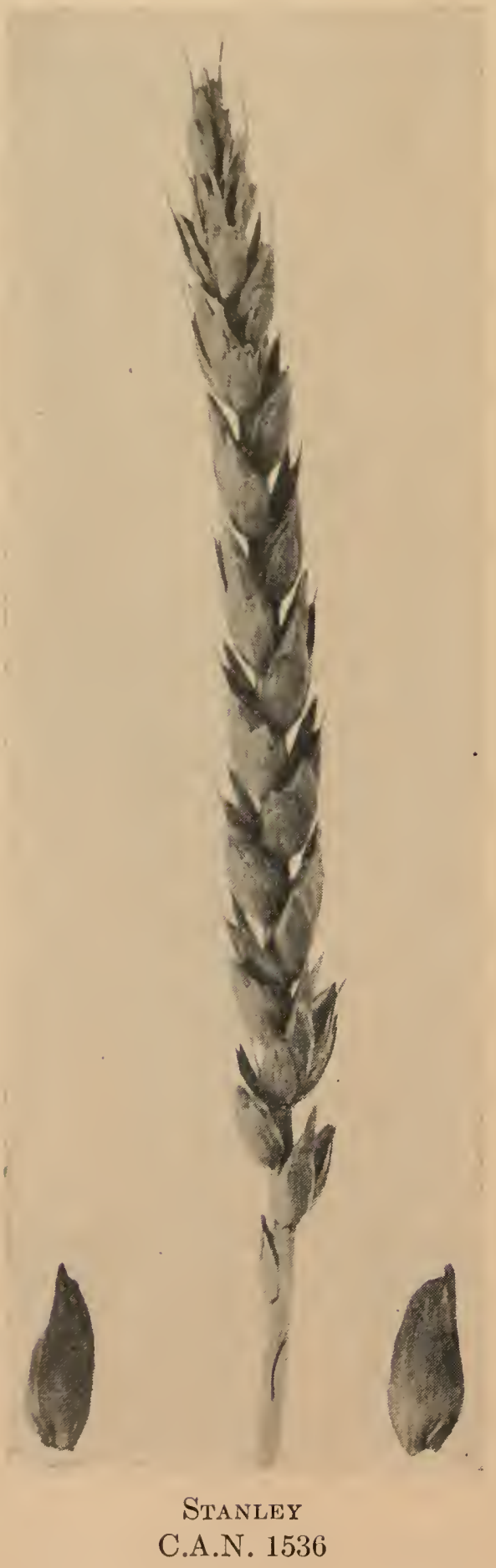
and smooth; kernels dark red, fairly long and fairly hard in texture; the crease rather deep as a rule; straw moderately strong; matures somewhat later than Marquis.

Milling And Baking Qualities: Stanley is inferior to Marquis in baking strength and flour color.

Status and Distribution: This variety was first distributed in the nineties but never became very widely established. With the introduction of Marquis, it was forced to take a very secondary place while Garnet and Reward following later almost completed its elimination. 


\section{Thatcher (Minn. 2303)}

(C.A.N. 1820)

Origin: Thatcher was produced from a cross made in 1921 at the Minnesota Agricultural Experiment Station, University of Minnesota, St. Paul, Minn., between (Marquis $\times$ Iumillo) $\times$ (Marquis $\times$ Kanred). The primary aim was to obtain a wheat of high quality for milling and baking purposes that was resistant to black stem rust and had desirable agronomic type. From one of the original crosses (Marquis $\times$ Iumillo), a bread wheat type was obtained with a considerable degree of resistance to stem rust under field conditions. From the Marquis $\times$ Kanred cross, a spring wheat was selected of good milling and baking quality that was immune to several forms of black stem rust and had high yielding ability. Thatcher originated from a cross between these two.

Description: Head resembles Marquis fairly closely but is somewhat shorter and denser. It also has a tendency to be slightly crooked or "twisted"; chaff white and smooth; glumes oblong in shape and about twice as long as wide; shoulders square; beaks acute, about $1 / 16^{\prime \prime}$ long, broad at the base and curving inwards; kernels red and hard but smaller than Marquis and usually somewhat dull in color; straw

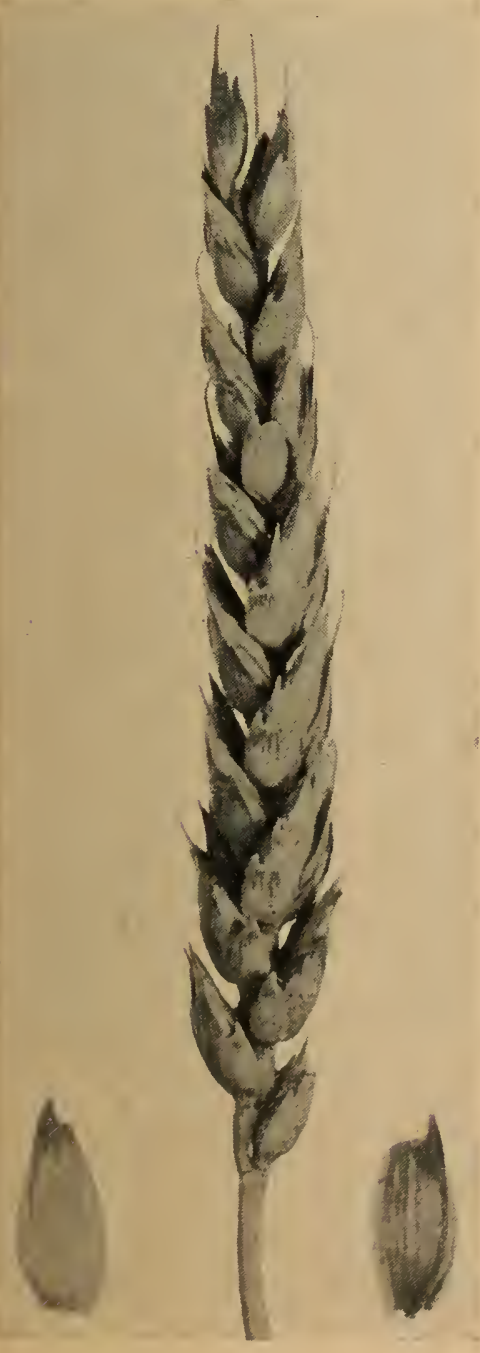

Thatcher C.A.N. 1820 of medium length, exceptionally strong and white in color; matures a few days earlier than Marquis, resistant to most forms of black stem rust in the field but very susceptible to bunt and leaf rust.

Thatcher has been a consistently high yielder since its introduction and in official tests has outyielded such common wheats as Marquis, Apex and Renown for many yeàrs.

Milling and Baking Qualities: Thatcher is superior to Marquis in baking strength. While it has a tendency to be low in bushel weight it mills readily and gives high flour yields. It produces a more creamy flour than Marquis.

Status and Distribution: It was released in Minnesota in the spring of 1934, when 2,000 bushels were distributed by the Minnesota Experiment Station to approved members of the Crop Improvement Association. It was licensed for sale in Canada in 1935, following a number of years of careful testing. In that year 8,000 bushels were grown in Manitoba. These 8,000 bushels plus 16,151 bushels imported from Minnesota were distributed for seeding in 1936. For the past 16 years, Thatcher has been the leading wheat variety in Saskatchewan, where the greatest wheat acreage in Canada is located. In 1953, 81 per cent of the acreage in that province was composed of Thatcher compared with 53 per cent in Alberta and 30 per cent in Manitoba. Since the introduction of Selkirk with its resistance to race $15 \mathrm{~B}$ stem rust, the wheat acreage of Thatcher has declined and in 1955 it ranked below Selkirk, Lee and Redman in Manitoba. In Saskatchewan and in Alberta, however, more than 56 per cent of the wheat acreage in both these provinces was seeded to this variety in 1955. 


\section{Type I c (Red Fife H)}

Origix: A selection out of common Red Fife made many years ago at the Central Experimental Farm, Ottawa.

D)scriptrox: Head similar in many respects to that of Early Red Fife, being beardless, oblong and fairly dense with a tendency toward a heavy or "clubbed" (clavate) tip; chaff white and smooth with rather wide, sloping shoulders and with short, broad beaks with rounded and slightly curved tips; matures slightly later than

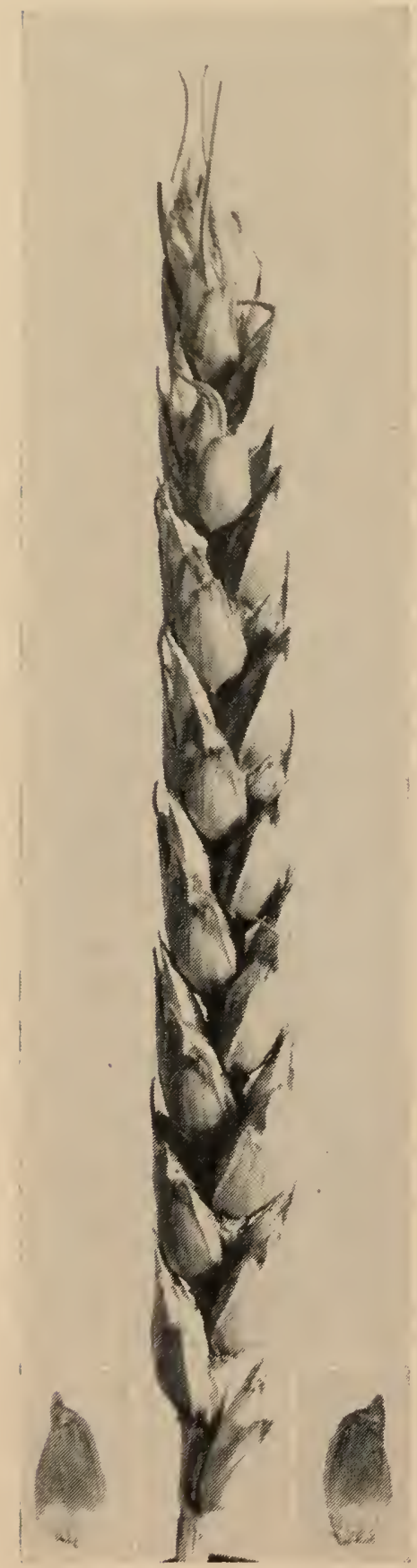
Marquis, straw about same length but weaker and more susceptible to both stem and leaf rust.

Milling and Baking Qualities: Considered in about the same class as Marquis.

Status And Distribution: This wheat became distributed fairly widely in the Prairie Provinces as a mechanical mixture in Marquis, dating from about 1922 , and became one of the most frequent impurities found in the latter variety. It is sometimes found in a relatively pure state, having been selected and propagated by the occasional farmer. It is not now a recognized commercial variety.

Type IC 


\section{White Russian}

(C.A.N. 1567)

OrIGIN: This variety originated as a selection out of Red Fife and was first grown at Ottawa in 1889 and at the Indian Head Experimental Farm in 1891. It is known under a number of names, amongst which Wellman's Fife is perhaps the most common.

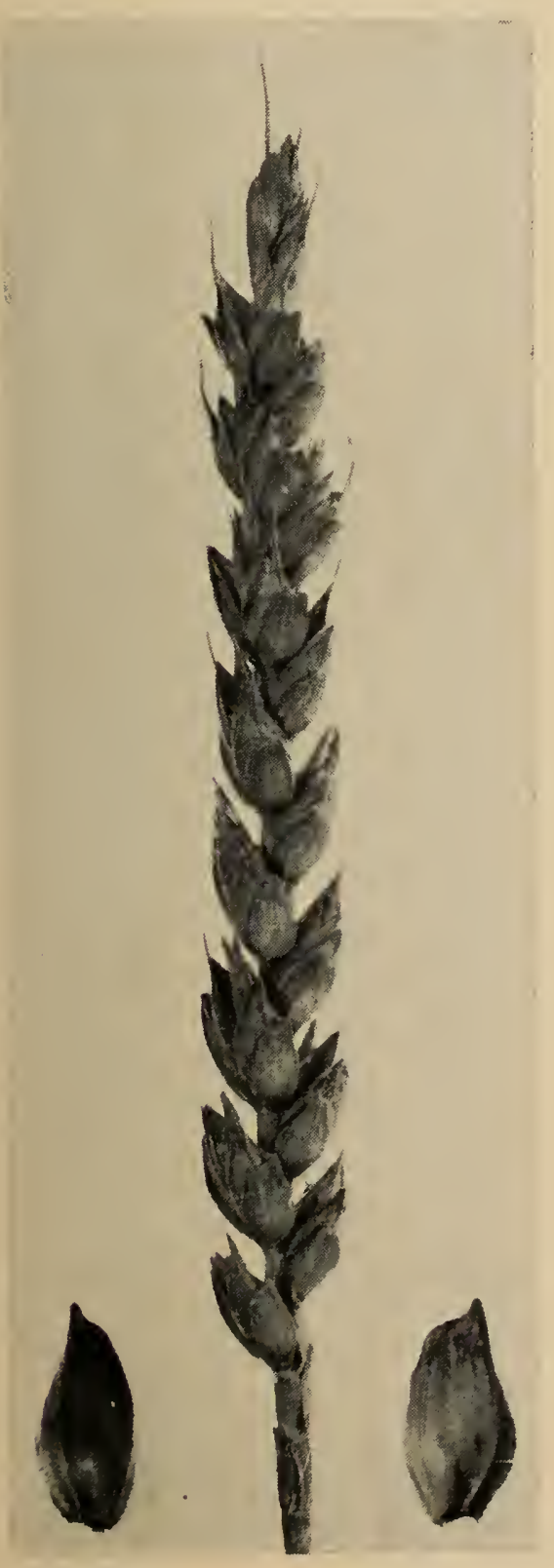

White Russian

C.A.N. 1567
Description: Head beardless, long and open; chaff white and smooth; kernels red and hard; straw very long and fairly strong; differs from Red Fife chiefly in length of straw and denseness of head; matures about the same time as Red Fife.

Milling And Baking Qualities: White Russian is inferior to Marquis for milling into flour for bread-making purposes.

Status And Distribution: It was grown up to a few years ago to a limited extent in New Brunswick, Nova Scotia and Prince Edward Island, but since the introduction of the Acadia variety White Russian has been found only rarely. 
EDMOND CLOUTIER, C.M.G., O.A., D.S.P.

QUEEN'S PRINTER AND CONTROLLER OF STATIONERY OTTAWA, 1957 